\title{
Petrogenesis AND STRUCTURAl POSITION OF THE EARLY ProterozoiC CHARNOCKITES OF THE TATARNIKOVSKY MASSIF IN THE SOUTH SIBERIAN POST-COLLISIONAL MAGMATIC BELT OF THE SIBERIAN CRATON
}

\author{
T. V. Donskaya, A. M. Mazukabzov, D. P. Gladkochub \\ Institute of the Earth's Crust, Siberian Branch of RAS, Irkutsk, Russia
}

\begin{abstract}
The article reports on the geological, mineralogical, geochemical and isotope-geochemical studies of granitoids (charnockites) from the Tatarnikovsky massif located in the northern part of the Baikal uplift of the Siberian craton basement. The age of the studied granitoids is $1.85 \mathrm{Ga}$. Like other unmetamorphosed granitoids and associated volcanic, the granitoids dated 1.88-1.84 Ga are abundant in the southern area of the Siberian craton. These rocks are a part of the South Siberian post-collisional magmatic belt. The Tatarnikovsky granitoids form a series of small massifs confined to the Davan tectonic zone. However, unlike the rocks of the Davan zone, these granitoids have not been subjected to dynamometamorphism, mylonitization and metasomatism, and seem younger than the geologic structure of this zone. The formation of granitoids coincides in time with the youngest formations in the North Baikal volcanoplutonic belt (1.85-1.84 Ga). The Tatarnikovsky granitoids have two facies varieties - coarse-grained and medium-fine-grained porphyric, the transition being gradual. Considering the mineral composition of the granitoids, specifically the presence of orthopyroxene, these rocks can be classified as charnockites. The research results presented in this article are based on the study of charnockites in the Tatarnikovsky massif, the largest in the Tatarnikovsky complex. The chemical composition of the Tatarnikovsky coarse-grained granitoids corresponds to monzonite and syenite, and fine-grained porphyry granitoids are granosyenite. All the studied granitoids are close to alkaline and calc-alkaline, metaluminous (ASI=0.83-0.97), ferrous $\left(\mathrm{FeO}^{*} /\left(\mathrm{FeO}^{*}+\mathrm{MgO}\right)=0.86-0.89\right)$ granite, with high concentrations of $\mathrm{Nb}, \mathrm{Y}, \mathrm{Zr}$, and $\mathrm{Ba}$, and low concentrations of Sr. According to their geochemical characteristics, the Tatarnikovsky granitoids correspond to A-type granite. These rocks show negative values $\varepsilon N d(t)=-1.4 \ldots-3.5$ and model age $\mathrm{T}_{\mathrm{Nd}} \mathrm{DM}=2.4-2.5 \mathrm{Ga}$. The temperature estimated for the initial stages of crystallization of granitoid melts suggests that granitoids formed at high temperatures, $890-960^{\circ} \mathrm{C}$ (i.e. the zircon saturation temperature). The granitoid melts crystallized in hypabyssal conditions at the pressure of 2.2-2.9 kbar, as well as in conditions of low or moderate oxygen fugacity. According to the mineralogical, geochemical and isotope-geochemical data, the Tatarnikovsky charnockite could have resulted from melting of mafic rocks from the lower crust (gabbroid, and ferrodiorite) which are products of differentiation of the tholeiitic mantle magmas that had intruded into the base of the continental crust. Taking into account the high concentrations of $\mathrm{Ba}$ and the positive anomalies of $\mathrm{Eu}$ in the distribution spectra of rare-earth elements (REE) of the coarse-grained granitoids, it can be suggested that these granitoids are the products of partial melting of the crustal
\end{abstract}

\section{RESEARCH ARTICLE}

Received: April 6, 2018

Handling Editor: K.Zh. Seminsky

For citation: Donskaya T.V., Mazukabzov A.M., Gladkochub D.P., 2018. Petrogenesis and structural position of the Early Proterozoic charnockites of the Tatarnikovsky massif in the South Siberian post-collisional magmatic belt of the Siberian craton. Geodynamics \& Tectonophysics 9 (2), 391-412. doi:10.5800/GT-2018-9-2-0352.

Для цитирования: Донская Т.В., Мазукабзов А.М., Гладкочуб Д.П. Петрогенезис и структурное положение раннепротерозойских чарнокитов татарниковского комплекса Южно-Сибирского постколлизионного магматического пояса Сибирского кратона // Геодинамика и тектонофизика. 2018. Т. 9. № 2. С. 391-412. doi:10.5800/GT-2018-9-2-0352. 
mafic source. The fine-grained porphyry granitoids with higher silica contents and lower $\mathrm{Ba}$ and $\mathrm{Zr}$ contents than those in the coarse-grained granitoids, as well as the negative anomalies of Eu in the REE distribution spectra, are the products of fractional crystallization of the granitoid melt. With regard to formation of the unified structure of the Siberian craton, the geodynamic setting for formation of the Tatarnikovsky charnockite is considered as postcollisional extension due to the fact that these rocks belong to the South Siberian post-collisional magmatic belt. However, on a more local scale of the Baikal uplift of the Siberian craton basement, we suggest that the intercontinental rifting setting was in place during the intrusion of the Tatarnikovsky granitoids, the rocks of the North Baikal volcanoplutonic belt, the granitoids of the Primorsky and Achadsky complexes that cross the rocks of the Akitkan fold belt, collision events in which ceased 1.98-1.97 Ga ago.

Key words: charnockites; A-type granires; geochemistry; continental rifting; post-collisional extension; Early Proterozoic; Siberian craton

\title{
ПЕТРОГЕНЕЗИС И СТРУКТУРНОЕ ПОЛОЖЕНИЕ РАННЕПРОТЕРОЗОЙСКИХ ЧАРНОКИТОВ ТАТАРНИКОВСКОГО КОМПЛЕКСА ЮЖНО-СИБИРСКОГО ПОСТКОЛЛИЗИОННОГО МАГМАТИЧЕСКОГО ПОЯСА СИБИРСКОГО
} КРАТОНА

\author{
Т. В. Донская, А. М. Мазукабзов, Д. П. Гладкочуб
}

\author{
Институт земной коры СО РАН, Иркутск, Россия
}

\begin{abstract}
Аннотация: В статье приводятся результаты геологического, минералогического, геохимического и изотопногеохимического изучения гранитоидов (чарнокитов) татарниковского комплекса, расположенного в северной части Байкальского краевого выступа фундамента Сибирского кратона. Гранитоиды имеют возраст 1.85 млрд лет и подобно другим неметаморфизованным гранитоидам и ассоциирующим с ними вулканитам с возрастом 1.88-1.84 млрд лет, широко распространенным в пределах южной части Сибирского кратона, входят в структуру Южно-Сибирского постколлизионного магматического пояса. Гранитоиды татарниковского комплекса образуют серию небольших массивов, приуроченных к Даванской зоне смятия. Однако, в отличие от пород Даванской зоны, гранитоиды не подвержены процессам динамометаморфизма, милонитизации и метасоматоза, что указывает на их формирование после становления структуры этой зоны. Образование гранитоидов совпадает по времени с формированием наиболее молодых образований Северо-Байкальского вулканоплутонического пояса (1.85-1.84 млрд лет). Среди гранитоидов татарниковского комплекса выделяются две фациальные разновидности с постепенными переходами: крупнозернистые породы и средне- и мелкозернистые порфировые породы. Минеральный состав гранитоидов, а именно присутствие в них ромбического пироксена, позволяет относить их к чарнокитам. Результаты, представленные в статье, основываются на изучении чарнокитов в самом крупном из массивов татарниковского комплекса - Татарниковском массиве. Крупнозернистые гранитоиды Татарниковского массива по своему химическому составу соответствуют монцонитам и сиенитам, а мелкозернистые порфировые гранитоиды - граносиенитам. Все гранитоиды по составу близки щелочным и известково-щелочным, умеренно-глиноземистым (ASI=0.83-0.97), железистым $\left(\mathrm{FeO}^{*} /(\mathrm{FeO} * \mathrm{MgO})=\right.$ =0.86-0.89) гранитам. Исследованные породы характеризуются высокими концентрациями $\mathrm{Nb}, \mathrm{Y}, \mathrm{Zr}, \mathrm{Ba}$ и пониженными содержаниями Sr. По своим геохимическим характеристикам породы соответствуют гранитам A-типа. Проанализированные гранитоиды Татарниковского массива характеризуются отрицательными величинами $\varepsilon N d(t)=-1.4 \ldots-3.5$ и модельным возрастом $\mathrm{T}_{\mathrm{Nd}} \mathrm{DM}=2.4-2.5$ млрд лет. Оценка температур начальных стадий кристаллизации гранитоидных расплавов показала, что формирование гранитоидов происходило при высоких температурах - 890-960 ${ }^{\circ} \mathrm{C}$ (температура насыщения расплава цирконом). Кристаллизация гранитоидных расплавов осуществлялась в гипабиссальных условиях при давлении 2.2-2.9 кбар, а также в условиях низкой или умеренной фугитивности кислорода. Минералогические, геохимические и изотопно-геохимические данные свидетельствуют о том, что чарнокиты татарниковского комплекса могли быть образованы за счет плавления мафических пород нижней коры (габброидов, ферродиоритов), которые были сформированы в результате дифференциации мантийных толеитовых магм, внедрившихся в основание континентальной коры. Высокие концентрации Ва и положительные $\mathrm{Eu}$ аномалии на спектрах распределения редкоземельных элементов (РЗЭ) крупнозернистых гранитоидов позволяют допускать, что гранитоиды формировались посредством частичного плавления корового мафического источника. Мелкозернистые порфировые гранитоиды, обнаруживающие более высокие содержания кремнезема и более низкие содержания Вa, $\mathrm{Zr}$ по сравнению с крупнозернистыми разностями, а также отрицательные Еu аномалии на спектрах распределения РЗЭ, были образованы в результате фракционной кристаллизации гранитоидного расплава. В масштабе становления единой структуры Сибирского кратона геодинамическая обстановка формирования чарнокитов татарников-
\end{abstract}


ского комплекса рассматривается как постколлизионное растяжение на основании их принадлежности к Южно-Сибирскому постколлизионному магматическому поясу. Однако в более локальном масштабе Байкальского выступа фундамента кратона внедрение гранитоидов татарниковского комплекса, так же как пород СевероБайкальского вулканоплутонического пояса, гранитоидов приморского и абчадского комплексов, пересекающих породы Акитканского складчатого пояса, коллизионные события в котором завершились на временном рубеже 1.98-1.97 млрд лет, происходило в обстановке внутриконтинентального рифтогенеза.

Ключевые слова: чарнокиты; граниты А-типа; геохимия; внутриконтинентальный рифтогенез; постколлизионное растяжение; ранний протерозой; Сибирский кратон

\section{1. ВВЕДЕНИЕ}

Гранитоиды и ассоциирующие с ними вулканиты с возрастом 1.88-1.84 млрд лет широко распространены в пределах южной части Сибирского кратона и объединяются в единый Южно-Сибирский постколлизионный магматический пояс (рис. 1) [Larin et al., 2003]. В настоящее время установлено, что породы Южно-Сибирского пояса фиксируют окончательную стадию становления структуры Сибирского кратона и, возможно, отражают процесс его вхождения в палеопротерозойский суперконтинент Колумбия [Didenko et al., 2009; Donskaya et al., 2013a]. Гранитоиды и вулканиты данного пояса характеризуются большим разнообразием составов, при этом среди них преобладают разности с геохимическими характеристиками гранитов А-типа [Donskaya et al., 2002, 2003, 2005, 2008, 2014; Larin et al., 2000, 2003, 2006, 2009; Levitskii et al., 2002; Nozhkin et al., 2003; Turkina, 2005; Turkina, Kapitonov, 2017; Turkina et al., 2003, 2006]. Максимальные вариации составов обнаруживают магматические породы Бирюсинского блока Присаянского выступа, среди которых отмечаются гранитоиды и вулканиты практически всех геохимических типов [Donskaya et al., 2014; Levitskii et al., 2002; Turkina, 2005; Turkina et al., 2003, 2006]. Напротив, магматические породы, имеющие только лишь составы, близкие гранитам А-типа, фиксируются в пределах Байкальского выступа фундамента кратона [Donskaya et al., 2003, 2005, 2007; Larin et al., 2003; Neymark et al., 1998; Petrova et al., 1997; Savel'eva, Bazarova, 2012]. Постколлизионные гранитоиды Байкальского выступа объединяются в несколько комплексов: приморский, ирельский, абчадский и татарниковский [Donskaya et al., 2003, 2005; Neymark et al., 1991, 1998; Petrova et al., 1997; Poller et al., 2005; Savel'eva, Bazarova, 2012; Sryvtsev et al., 1980]. Гранитоиды каждого комплекса, несмотря на отнесение к одному геохимическому типу, обнаруживают ряд специфических характеристик. В частности, среди гранитоидов приморского комплекса отмечаются рапакивиподобные образования [Donskaya et al.,
2003, 2005; Savel'eva, Bazarova, 2012]. Гранитоды ирельского комплекса пространственно ассоциируют с близкими им по возрасту и составу вулканитами акитканской серии и совместно входят в состав Северо-Байкальского вулканоплутонического пояса [Donskaya et al., 2005, 2008; Larin et al., 2003, 2006; Neymark et al., 1991, 1998]. Граниты абчадского комплекса составляют единую вулканоплутоническую ассоциацию с вулканитами иловирьской свиты (Абчадский пояс) [Neymark et al., 1998]. Гранитоиды татарниковского комплекса, единственные среди всех постколлизионных гранитоидов Южно-Сибирского постколлизионного магматического пояса, были отнесены к группе чарнокитов [Sryvtsev et al., 1980; Larin et al., 2009]. Чарнокиты ортопироксенсодержащие (или, реже, фаялитсодержащие) гранитоиды, преимущественно ассоциирующиеся с гранулитами, но иногда образующие неметаморфизованные интрузии, внедрение которых имело место в различных тектонических обстановках [Frost C.D., Frost B.R., 2008]. Такой необычный (чарнокитовый) состав постколлизионных гранитоидов татарниковского комплекса дал основание для определения цели и задач настоящего исследования. В статье, на основании детального изучения геологического положения гранитоидов татарниковского комплекса, их петрографических, минералогических и геохимических характеристик, приводится оценка возможных источников гранитоидных расплавов и условий их кристаллизации, а также рассматривается геологическая ситуация в регионе на момент внедрения чарнокитов.

\section{2. ГЕОЛОГИЧЕСКОЕ СТРОЕНИЕ РАЙОНА РАСПРОСТРАНЕНИЯ ГРАНИТОИДОВ ТАТАРНИКОВСКОГО КОМПЛЕКСА И ВОЗРАСТ ГРАНИТОИДОВ}

Гранитоиды (чарнокиты) татарниковского комплекса образуют серию небольших массивов в северной части Байкальского краевого выступа фун- 


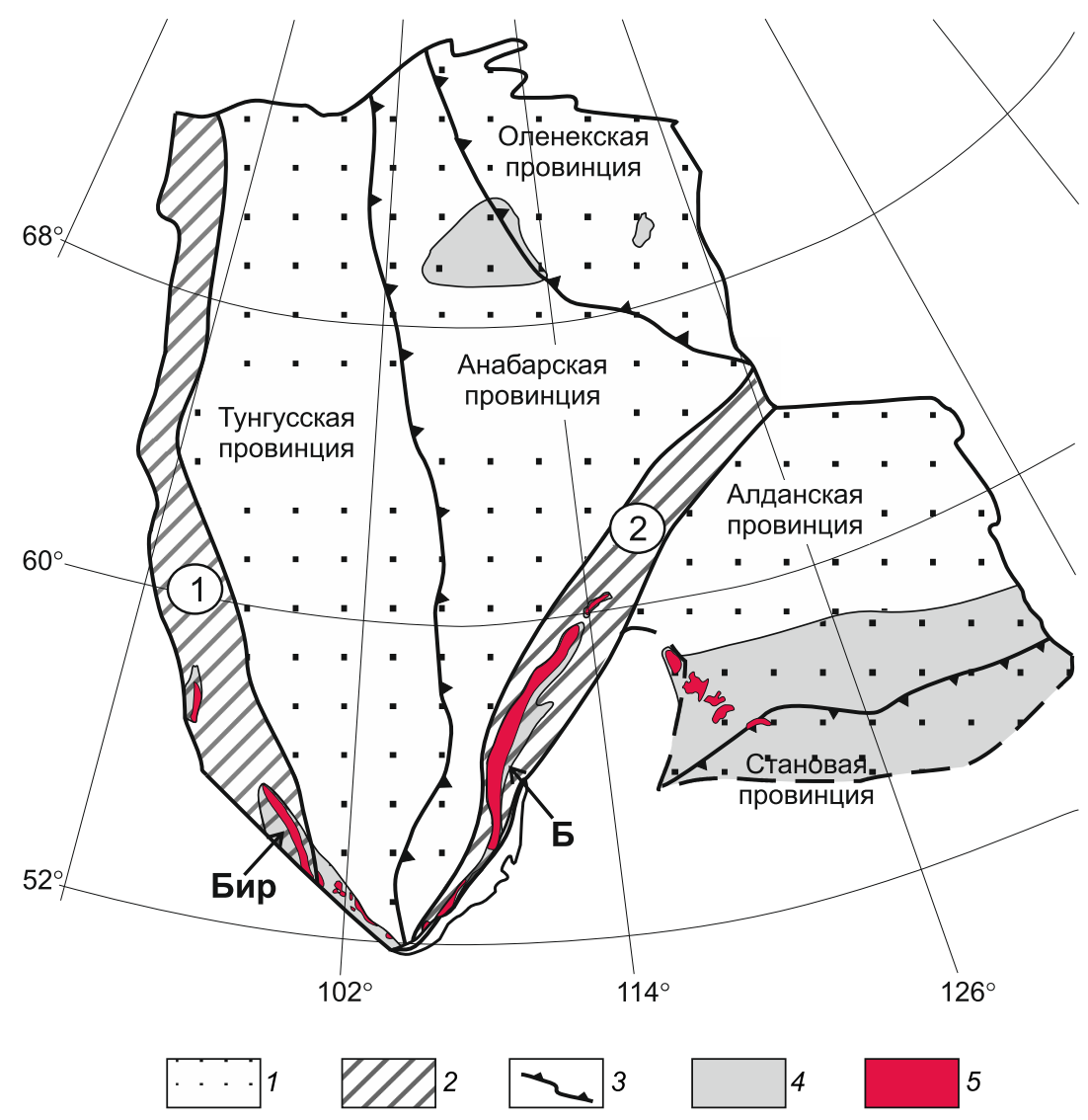

Рис. 1. Схема основных тектонических элементов Сибирского кратона и выходы раннепротерозойских пород Южно-Сибирского постколлизионного магматического пояса (модифицированная после [Rosen, 2003; Gladkochub et al., 2006; Larin et al., 2003]).

1 - основные супертеррейны (провинции); 2 - раннепротерозойские складчатые пояса; 3 - шовные зоны; 4 - выступы фундамента; 5 - раннепротерозойские породы Южно-Сибирского постколлизионного магматического пояса. Цифры на рисунке в кружках: 1 - Ангарский складчатый пояс; 2 - Акитканский складчатый пояс. Буквы на рисунке: Бир - Бирюсинский блок Присаянского выступа; Б - Байкальский выступ.

Fig. 1. Schematic map showing the main tectonic elements of the Siberian craton and the distribution of the Early Proterozoic rocks of the South Siberian post-collisional magmatic belt (modified after [Rosen, 2003; Gladkochub et al., 2006; Larin et al., 2003]).

1 - main superterranes (provinces); 2 - Early Proterozoic folded belts; 3 - suture zones; 4 - basement uplifts; 5 - Early Proterozoic rocks of the South Siberian post-collisional magmatic belt. Circled numbers: 1 - Angara folded belt; 2 - Akitkan folded belt. Letters: Бир Biryusa block of the Prisayansky uplift; 5 - Baikal uplift.

дамента Сибирского кратона и приурочены к Даванской зоне смятия [Sryvtsev et al., 1980] (рис. 2, 3). Даванская зона смятия представляет собой контролируемую системой разломов субмеридиональную зону, сложенную тектонизированными, динамометаморфизованными, милонитизированными и метасоматизированными породами, образованными по раннепротерозойским породам чуйской и сарминской серий, архейским - раннепротерозойским (?) плагиогранитам, а также по раннепротерозойским образованиям нижних частей разреза акитканской серии и гранитоидам ирельского комплекса Северо-Байкальского вулканоплутонического пояса [Sryvtsev et al., 1980; Kushch, Makrygina, 2014].
В северной части полосы выходов гранитоидов татарниковского комплекса (на широте р. Окунайка) гранитоиды картируются в форме мелких изометричных тел площадью до 2-5 км². В южной части располагается самый крупный Татарниковский массив площадью 98 км². В плане этот массив имеет сложную неправильную форму и состоит из двух крупных тел, соединенных узким перешейком.

Породы татарниковского комплекса представлены преимущественно кварцевыми монцодиоритами, кварцевыми монцонитами и гранодиоритами [Sryvtsev et al., 1980; Larin et al., 2009]. Среди гранитоидов выделяются две фациальные разновидности с постепенными переходами: крупнозернистые породы и средне- и мелкозернистые порфировые 


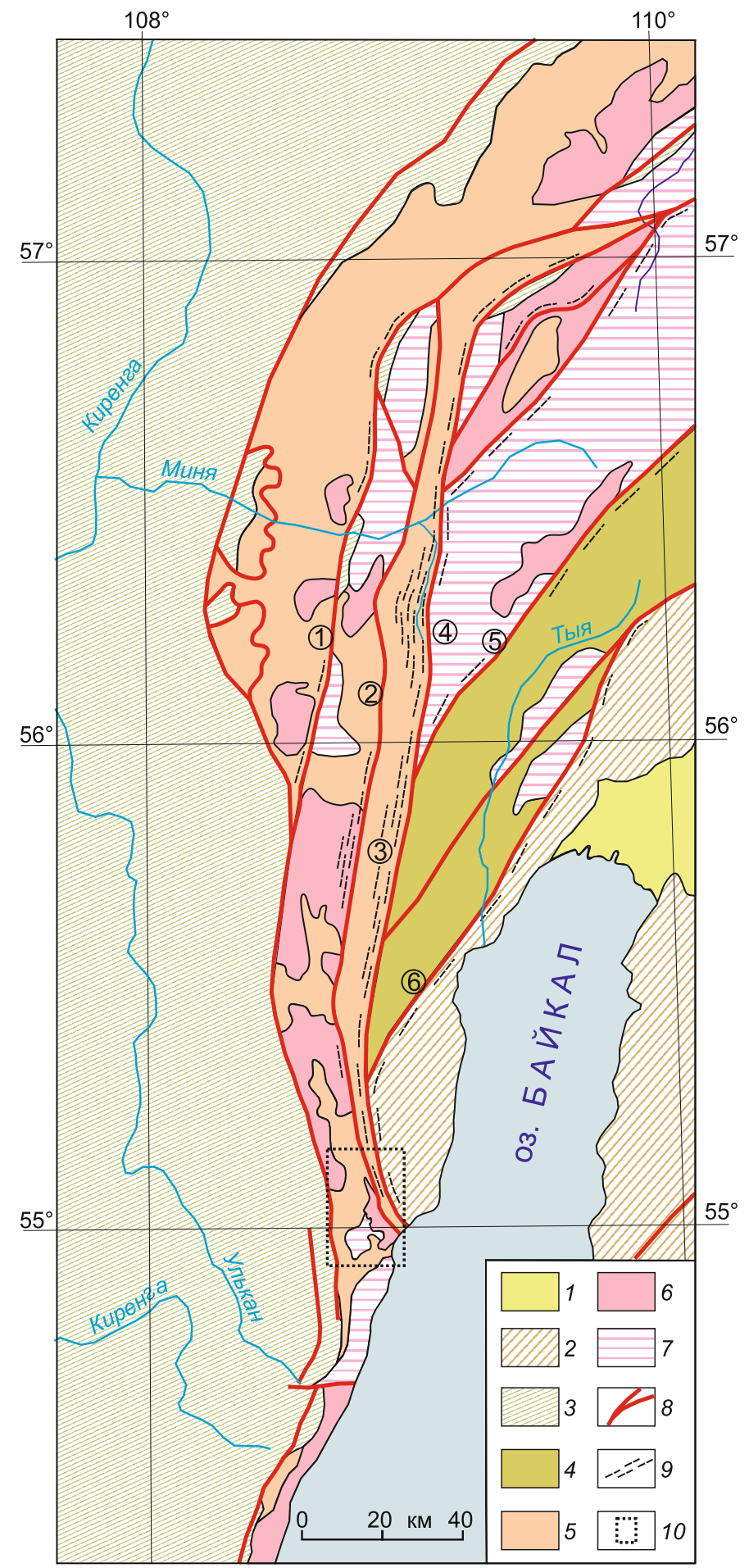

породы. В гранитоидах отмечаются ксенолиты вмещающих пород, при этом их повышенное количество сосредоточено в эндоконтактовой зоне. Минеральный состав гранитоидов, а именно присутствие в них ромбического пироксена, дал основание относить их к чарнокитам [Sryvtsev et al., 1980; Larin et al., 2009].

Долгое время возраст гранитоидов татарниковского комплекса варьировался от среднего протерозоя до раннего палеозоя. В работе Н.А. Срывцева с соавторами [Sryvtsev et al., 1980] Rb-Sr методом по
Рис. 2. Схема геологического строения северной части Байкальского краевого выступа фундамента Сибирского кратона ([Kuznetsov, Khrenov, 1989], с добавлениями авторов).

1 - кайнозойские отложения; 2 - Центрально-Азиатский складчатый пояс; 3-7 - Сибирский кратон: 3 - платформенный чехол (венд - ранний палеозой), 4 - образования перикратонного опускания (неопротерозой), 5-6 - Северо-Байкальский вулканоплутонический пояс (палеопротерозой): 5 - акитканская серия, 6 - интрузивные комплексы, 7 - архей-палеопротерозойские комплексы консолидированной коры кратона (нерасчлененные); 8 - основные разломы (1 Окунайский, 2 - Кунерминский, 3 - Даванская зона смятия, 4 - Левоминский, 5 - Абчадский, 6 - Мамско-Нюрундуканский); 9 - площадное проявление динамометаморфизма, милонитизации и метасоматоза; 10 - район работ.

Fig. 2. Schematic geological structure of the northern part of the Baikal uplift of the Siberian craton basement ([Kuznetsov, Khrenov, 1989], including the data added by the authors).

1 - Cenozoic deposits; 2 - Central Asian folded belt; 3-7 - Siberian craton: 3 - platform cover (Vendian - Early Paleozoic), 4 pericratonic subsidence rocks (Neoproterozoic), 5-6 - North Baikal volcanoplutonic belt (Paleoproterozoic): 5 - Akitkan series, 6 - intrusive complexes, 7 - Archean - Paleoproterozoic complexes of the consolidated crust of the craton (undivided); 8 - major faults 11 - Okunay, 2 - Kunerma, 3 - Davan zone, 4 - Levominsk, 5 - Abchad, 6 - Mama-Nyurundukan); 9 - area features of dynamometamorphism, myonitization and metasomatism; 10 - study area. валу горных пород возраст гранитоидов был определен как $2030 \pm 60$ млн лет. Однако U-Pb методом по циркону (TIMS) для гранитоида Татарниковского массива татарниковского комплекса А.М. Лариным с соавторами [Larin et al., 2009] была получена оценка возраста $1853 \pm 5$ млн лет. Данная оценка возраста в настоящее время принимается как наиболее точная для кристаллизации расплавов, родоначальных для гранитоидов татарниковского комплекса [Larin et al., 2009]. Полученное значение возраста совпадает с возрастом наиболее молодых 

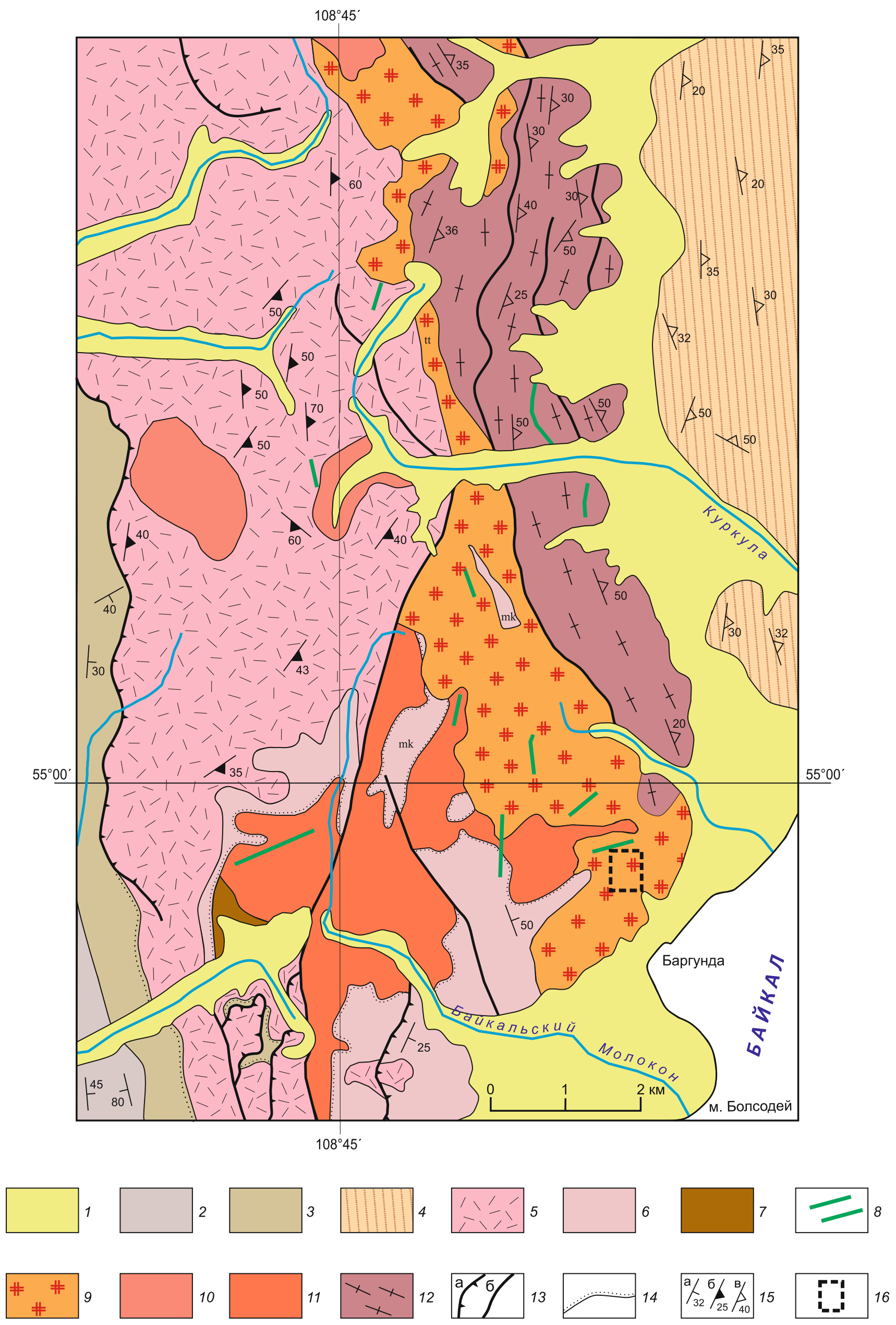
Рис. 3. Геологическое строение бассейна рек Байкальский Молокон и Куркула ([Aleksandrov, 1990], с добавлениями авторов).

1 - голоценовые отложения (аллювиальные, ледниковые); 2 - поздневендские отложения (ушаковская свита); 3 - ранневендские отложения (байкальская серия); 4 - позднерифейские образования (нерундуканская толща); 5-7 - раннепротерозойские образования: 5-6 - акитканская серия: 5 - вулканиты (хибеленская свита), 6 - вулканогенно-терригенные породы (малокосинская свита), 7 - метаосадочные и вулканогенные образования (иликтинская свита сарминской серии); 8-10 - раннепротерозойские магматические образования: 8 - габбро-долериты (чайский комплекс), 9 - чарнокиты (татарниковский комплекс), 10 гранитоиды (ирельский комплекс); 11 - архейские - раннепротерозойские (?) плагиограниты; 12 - динамометаморфиты по породам акитканской серии; 13 - разрывные нарушения: а - надвиги, б - сдвиго-взбросы; 14 - угловое несогласие; 15 - залегание плоскостных элементов: а - слоистости, б - флюидального течения, в - сланцеватости, полосчатости; 16 - участок отбора проб.

Fig. 3. Geological structure of the basin of the Baikal Molokon and Kurkula rivers ([Aleksandrov, 1990], including the data added by the authors).

1 - Holocene sediments (alluvial, glacial); 2 - Late Vendian deposits (Ushakovskaya suite); 3 - Early Vendian deposits (Baikal series); 4 Late Riphean rocks (Nerundukan stratum); 5-7 - Early Proterozoic rocks: 5-6 - Akitkan series: 5 - volcanics (Khibelen suite), 6 - volcanogenic-terrigenous rocks (Malokosinskaya suite); 7 - metasedimentary and volcanogenic rocks (Ilikta suite of the Sarma series); 8-10 - Early Proterozoic magmatic rocks: 8 - gabbro-dolerites (Chaya complex), 9 - charnockites (Tatarnikovsky complex), 10 - granitoids (Irel complex); 11 - Archean - Early Proterozoic (?) plagiogranites; 12 - dynamometamorphites in the Akitkan series; 13 - faults: a - thrust, 6 reverse fault with shear component; 14 - angular unconformity; 15 - occurrence of planar elements: a - bedding, 6 - fluid flow, B - schistosity, foliation; 16 - sampling site.

образований Северо-Байкальского вулканоплутонического пояса, а именно трахириолитов верхней части акитканской серии в северной части пояса (1854 \pm 5 млн лет) [Larin et al., 2003], риолитов верхней части акитканской серии в южной части пояса

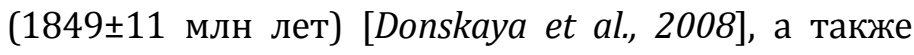
комбинированных даек южной части Северо-Бай-

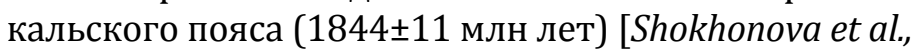
2010]. В то же время полученный возраст по гранитоидам татарниковского комплекса меньше, чем возраст пород нижней (малокосинской) свиты акитканской серии, а также большинства пород средних и верхних частей разреза акитканской серии и гранитоидов ирельского комплекса $(1878 \pm 4-1863 \pm 9$ млн лет [Donskaya et al., 2007, 2008; Neymark et al., 1991; Larin et al., 2003; Poller et al., 2005]).

\section{3. СТРУКТУРНАЯ ПОЗИЦИЯ ГРАНИТОИДОВ ТАТАРНИКОВСКОГО КОМПЛЕКСА}

По отношению к региональной структуре северной части Байкальского краевого выступа фундамента Сибирского кратона интрузивные тела гранитоидов татарниковского комплекса располагаются преимущественно согласно. Характер границ с вмещающими породами различен и зависит от компетентности последних. С гнейсами метаморфического комплекса и терригенно-вулканогенными породами малокосинской свиты акитканской серии большинство контактов дискордантно. В результате механического воздействия интрузивов во вмещающих образованиях произошло интен- сивное складкообразование и местами песчаники, конгломераты и гнейсы, примыкающие к интрузии, принимают довольно крутое падение с углами $70-80^{\circ}$. Особенно хорошо это видно в обнажениях на левом борту р. Поперечной, где наблюдаются небольшие куполовидные выступы гранитоидов. Углы падения восточных поверхностей тел, как правило, более пологие, чем западные $\left(25-35^{\circ}\right.$ против $40-50^{\circ}$ ), с общим падением на восток, так что вертикальный разрез интрузивов характеризуется асимметричной формой с осевой поверхностью, наклоненной к западу. На основании этих структурных признаков можно сделать вывод, что тела гранитоидов обладают в верхней части куполообразной формой.

Внутренняя структура массивов не несет следов линейности и полосчатости и до самого контакта с вмещающими породами они остаются массивными и полнокристаллическими. Лишь в районе гольца Баргунда и местами на водоразделе рек Татарниковское Русло и Куркула отмечается полоса краевых гнейсов мощностью до 200 м, плоскости гнейсования которых параллельны поверхности контактов. В периферической зоне тел часто наблюдаются краевые сбросы, выполненные дайками основных пород.

Гранитоиды татарниковского комплекса локально затронуты разрывными нарушениями взбросо-надвигового типа с хрупким типом деформаций, возникновение которых связано с каледонскими событиями, проявившимися в образованиях Северо-Байкальского вулканоплутонического пояса и на сопредельных территориях. 


\section{4. ОБЪЕКТЫ И МЕТОДЫ ИССЛЕДОВАНИЙ}

Детальные петрографические, минералогические, геохимические и изотопно-геохимические исследования были проведены для гранитоидов Татарниковского массива татарниковского комплекса. Этот массив является самым южным в цепочке массивов комплекса и расположен недалеко от залива Баргунда оз. Байкал, в районе руч. Татарниковский (рис. 3). Гранитоиды Татарниковского массива прорывают архейские - раннепротерозойские (?) плагиограниты, раннепротерозойские метаосадочные породы иликтинской свиты сарминской серии, а также раннепротерозойские породы малокосинской и хибеленской свит акитканской серии Северо-Байкальского вулканоплутонического пояса, в том числе и динамометаморфизованные породы Даванской зоны смятия, образованные по породам акитканской серии (рис. 3).

Представительные образцы гранитоидов Татарниковского массива были проанализированы на содержание главных, редких и редкоземельных элементов. В трех образцах были изучены составы породообразующих минералов. Для двух образцов было выполнено определение изотопного состава $\mathrm{Nd}$.

Изучение составов минералов было проведено на модернизированном электронно-зондовом микроанализаторе МАР-3 в Геологическом институте СО РАН г. Улан-Удэ (аналитик С.В. Канакин). Условия исследования на микроанализаторе МАР-3 составили: ускоряющее напряжение 20 кВ, ток зонда 45-50 нА, диаметр зонда 2-3 мкм, ошибка, обусловленная статистикой счета, не превышала $1 \%$ на сумму.

Определение содержаний главных элементов выполнено методом силикатного анализа в ЦКП «Геодинамика и геохронология» ИЗК СО РАН (аналитик Г.В. Бондарева). Определение содержаний редких и редкоземельных элементов выполнено методом ICP-MS в Лимнологическом институте CO РАН, ОПЦКП «Ультрамикроанализ», на квадрупольном масс-спектрометре Agilent 7500се (Agilent Technologies Inc., США) (аналитик С.В. Пантеева). Концентрации элементов в образцах рассчитаны относительно международных стандартов G-2, GSP-2. Химическое разложение проб для ICP-MS анализа проведено в ЦКП «Геодинамика и геохронология» ИЗК СО РАН методом сплавления с метаборатом лития по методике [Panteeva et al., 2003], что позволило достичь полного растворения всех минералов. Ошибка определений содержаний редких и редкоземельных элементов методом ICP-MS coставляла не более $5 \%$.

Определения содержаний $\mathrm{Sm}$ и $\mathrm{Nd}$ и изотопных составов $\mathrm{Nd}$ для двух проб были выполнены в Геологическом институте КНЦ РАН (г. Апатиты) и опубликованы в работе [Gladkochub et al., 2009].

\section{5. ПЕТРОГРАФИЧЕСКАЯ И МИНЕРАЛОГИЧЕСКАЯ ХАРАКТЕРИСТИКА ГРАНИТОИДОВ}

Исследованные гранитоиды Татарниковского массива представляют собой преимущественно массивные крупнозернистые породы, среди которых отмечаются более мелкозернистые порфировые разности.

Крупнозернистые гранитоиды представляют собой породы гипидиоморфнозернистой структуры, главными породообразующими минералами которых являются калиевый полевой шпат (30-35 \%) и плагиоклаз (35-36 \%). В меньших количествах в породах представлены кварц (9-10\%), пироксен (5-6 \%), амфибол (5-7 \%), биотит (4-5\%), рудные минералы (3-5 \%). В качестве акцессорных минералов отмечаются сфен, ортит, циркон, апатит. Для гранитоидов характерно замещение плагиоклаза калиевым полевым шпатом, и наоборот, замещение калиевого полевого шпата плагиоклазом с образованием мирмекитов. Кроме того, отмечается большое количество пертитовых вростков альбита в калиевом полевом шпате. Пироксен замещается роговой обманкой и биотитом, а также хлоритом и эпидотом. Гранитоиды подвержены незначительным вторичным изменениям, выраженным хлоритизацией, альбитизацией, серицитизацией и соссюритизацией отдельных минералов.

Мелкозернистые гранитоиды характеризуются порфировой структурой. Главные породообразующие минералы представлены плагиоклазом (3540 \%), калиевым полевым шпатом (30-32 \%), кварцем (10-12 \%). Второстепенные минералы - амфибол (9-10\%), биотит (5-6\%), рудный минерал (около 4 \%). Акцессории - сфен, циркон, апатит. Породы состоят из большого количества фенокристаллов плагиоклаза, калиевого полевого шпата, амфибола и биотита. Промежутки между фенокристаллами выполнены полнокристаллической основной массой, в которой помимо плагиоклаза, калиевого полевого шпата, амфибола и биотита также присутствует кварц. Вторичные изменения проявлены в виде соссюритизации и альбитизации отдельных минералов.

Пироксены были проанализированы в одном образце крупнозернистого гранитоида (№ 0270). Согласно классификации пироксенов [Morimoto et al., 1988], химический состав одного проанализированного пироксена соответствует пижониту (Wo $\left.{ }_{15} \mathrm{En}_{12} \mathrm{Fs}_{73}\right)$, а второго - ферросилиту $\left(\mathrm{Wo}_{2} \mathrm{En}_{7} \mathrm{Fs}_{90}\right)$ (табл. 1).

Амфиболы в гранитоидах Татарниковского массива относятся к группе кальциевых амфиболов по классификации [Leake, 1997], удовлетворяющей условию $\mathrm{Ca}_{\mathrm{B}} \geq 1.50$, Ti<0.50 (табл. 2). Проанализиро- 
Т а б л и ц а 1. Представительные анализы пироксенов и их кристаллохимические формулы

$\mathrm{T}$ a b l e 1. Representative analyses and crystallochemical formulas for pyroxene

\begin{tabular}{|c|c|c|}
\hline Образец & 0270 & 0270 \\
\hline Минерал & Px_1 & Px_2 \\
\hline $\mathrm{SiO}_{2}$ & 48.77 & 47.42 \\
\hline $\mathrm{TiO}_{2}$ & 0.30 & 0.00 \\
\hline $\mathrm{Al}_{2} \mathrm{O}_{3}$ & 1.32 & 0.12 \\
\hline $\mathrm{FeO}$ & 36.98 & 46.47 \\
\hline $\mathrm{MnO}$ & 1.43 & 2.15 \\
\hline $\mathrm{MgO}$ & 3.48 & 2.25 \\
\hline $\mathrm{CaO}$ & 6.09 & 0.90 \\
\hline $\mathrm{Na}_{2} \mathrm{O}$ & 0.22 & 0.00 \\
\hline $\mathrm{K}_{2} \mathrm{O}$ & 0.17 & 0.00 \\
\hline Сумма & 98.74 & 99.30 \\
\hline $\mathrm{Si}$ & 2.025 & 2.032 \\
\hline $\mathrm{Ti}$ & 0.009 & 0.000 \\
\hline $\mathrm{Al}$ & 0.064 & 0.006 \\
\hline $\mathrm{Fe}$ & 1.284 & 1.665 \\
\hline Mn & 0.050 & 0.078 \\
\hline $\mathrm{Mg}$ & 0.215 & 0.144 \\
\hline $\mathrm{Ca}$ & 0.271 & 0.041 \\
\hline $\mathrm{Na}$ & 0.018 & 0.000 \\
\hline $\mathrm{K}$ & 0.009 & 0.000 \\
\hline Сумма & 3.947 & 3.965 \\
\hline Wo & 15 & 2 \\
\hline En & 12 & 7 \\
\hline Fs & 73 & 90 \\
\hline
\end{tabular}

П р и м е ч а н и е. Расчет кристаллохимических формул проводился на шесть атомов кислорода. Расчет миналов Еn (энстатит), Wo (волластонит) и Fs (ферросилит) проведен в соответствии с методикой [Morimoto, 1988].

$\mathrm{N}$ o t e. The crystallochemical formulas were calculated for six atoms of oxygen. The minals of En (enstatite), Wo (wollastonite), and Fs (ferrosilite) were calculated under the procedure described in [Morimoto, 1988].

ванные амфиболы характеризуются $\mathrm{Si}$ ф.е. > 6.5 (табл. 2, рис. $4, a$ ). Все они обнаруживают высокие значения отношения $\mathrm{Fe}^{2+} /\left(\mathrm{Mg}^{2} \mathrm{Fe}^{2+}\right)=0.72-0.88$ и, соответственно, пониженные $\mathrm{Mg} /\left(\mathrm{Mg}+\mathrm{Fe}^{2+}\right)=0.12-$ 0.28. Составы амфиболов из гранитоидов Татарниковского массива близки ферроэдениту при условии $(\mathrm{Na}+\mathrm{K})_{\mathrm{A}} \geq 0.5$ и железистой роговой обманке при $(\mathrm{Na}+\mathrm{K})_{\mathrm{A}}<0.5$ (табл. 2 , рис. $\left.4, a\right)$.

Биотиты были проанализированы только в одном образце мелкозернистого гранитоида (№ 0273). Они характеризуются повышенной железистостью $(\mathrm{Fe} /(\mathrm{Fe}+\mathrm{Mg})=0.82-0.84)$ и по составу наиболее близки анниту (табл. 3 , рис. 4, б).

$\mathrm{Fe}$-Ti окислы, проанализированные в гранитоидах Татарниковского массива, соответствуют по составу ильмениту (Тi ф.е.=0.71-1.01) (табл. 4).

\section{6. ГЕОХИМИЧЕСКАЯ ХАРАКТЕРИСТИКА ГРАНИТОИДОВ}

Проанализированные гранитоиды Татарниковского массива характеризуются содержаниями $\mathrm{SiO}_{2}=60-64$ мас. \% (табл. 5). Все проанализирован- ные породы принадлежат умеренно-щелочной серии (рис. 5, a). Крупнозернистые гранитоиды по своему химическому составу соответствуют монцонитам и сиенитам, в то время как мелкозернистые гранитоиды порфировой структуры обнаруживают более низкие концентрации щелочей и по составу соответствуют граносиенитам [Sharpenok et al., 2013] (рис. 5, a). Согласно классификации Б.Р. Фроста с соавторами [Frost et al., 2001], исследованные гранитоиды относятся к железистым $\left(\mathrm{FeO}^{*} /\left(\mathrm{FeO}^{*}+\mathrm{MgO}\right)=0.86-0.89\right), \quad$ умеренно-глиноземистым образованиям (ASI=0.83-0.97) (рис. 5, б, в). На диаграмме $\left(\mathrm{Na}_{2} \mathrm{O}+\mathrm{K}_{2} \mathrm{O}-\mathrm{CaO}\right)-\mathrm{SiO}_{2}$ крупнозернистые гранитоиды попадают в поле щелочных пород, а мелкозернистые - в поле известково-щелочных пород (рис. 5, 2). По перечисленным выше петрогеохимическим характеристикам гранитоиды Татарниковского массива обнаруживают сходство с щелочными и известково-щелочными умеренноглиноземистыми железистыми гранитами [Frost C.D., Frost B.R., 2011].

Исследованные гранитоиды Татарниковского массива характеризуются высокими концентра- 
T.V. Donskaya et al.: Petrogenesis and structural position of the Early Proterozoic charnockites...

Т а б л и ц а 2. Представительные анализы амфиболов и их кристаллохимические формулы

$\mathrm{T}$ a b l e 2. Representative analyses and crystallochemical formulas for amphibole

\begin{tabular}{|c|c|c|c|c|c|c|}
\hline Образец & 0268 & 0268 & 0270 & 0270 & 0273 & 0273 \\
\hline Минерал & Amp_1 & Amp_2 & Amp_1 & Amp_2 & Amp_1 & Amp_2 \\
\hline $\mathrm{SiO}_{2}$ & 41.66 & 41.67 & 43.27 & 40.56 & 42.79 & 41.88 \\
\hline $\mathrm{Al}_{2} \mathrm{O}_{3}$ & 8.08 & 7.76 & 7.30 & 7.72 & 7.70 & 7.85 \\
\hline $\mathrm{Fe}_{2} \mathrm{O}_{3}$ & 5.34 & 7.34 & 7.48 & 8.14 & 4.26 & 4.30 \\
\hline $\mathrm{FeO}$ & 26.36 & 24.33 & 21.68 & 24.27 & 24.79 & 24.89 \\
\hline $\mathrm{CaO}$ & 10.42 & 10.30 & 10.45 & 10.34 & 11.48 & 11.12 \\
\hline $\mathrm{Na}_{2} \mathrm{O}$ & 1.42 & 1.57 & 1.70 & 1.00 & 1.18 & 1.38 \\
\hline $\mathrm{K}_{2} \mathrm{O}$ & 1.31 & 1.24 & 1.08 & 2.33 & 1.11 & 1.10 \\
\hline Сумма & 98.80 & 99.37 & 98.97 & 98.31 & 99.11 & 98.38 \\
\hline $\mathrm{Si}$ & 6.611 & 6.549 & 6.715 & 6.514 & 6.690 & 6.613 \\
\hline $\mathrm{Ti}$ & 0.191 & 0.200 & 0.081 & 0.091 & 0.137 & 0.200 \\
\hline $\mathrm{Mn}$ & 0.083 & 0.091 & 0.065 & 0.101 & 0.089 & 0.073 \\
\hline $\mathrm{Mg}$ & 0.467 & 0.656 & 1.117 & 0.589 & 0.923 & 0.857 \\
\hline $\mathrm{Ca}$ & 1.771 & 1.735 & 1.737 & 1.779 & 1.923 & 1.881 \\
\hline $\mathrm{Na}$ & 0.438 & 0.478 & 0.512 & 0.311 & 0.359 & 0.422 \\
\hline $\mathrm{K}$ & 0.265 & 0.248 & 0.214 & 0.477 & 0.221 & 0.221 \\
\hline Сумма & 15.475 & 15.461 & 15.463 & 15.567 & 15.503 & 15.524 \\
\hline $\mathrm{Fe}^{2+} /\left(\mathrm{Fe}^{2+}+\mathrm{Mg}\right)$ & 0.88 & 0.83 & 0.72 & 0.85 & 0.78 & 0.79 \\
\hline$(\mathrm{Na}+\mathrm{K})_{\mathrm{A}}$ & 0.475 & 0.461 & 0.463 & 0.567 & 0.503 & 0.524 \\
\hline
\end{tabular}

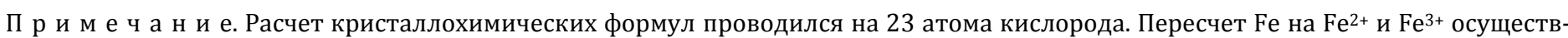
лялся по методике [Droop, 1987]. Формульные количества (Na+K) А рассчитаны по методике [Leake, 1997].

$\mathrm{N}$ o t e. The crystallochemical formulas were calculated for 23 atoms of oxigen. The conversion of $\mathrm{Fe}$ to $\mathrm{Fe}^{2+}$ and $\mathrm{Fe}^{3+}$ was carried out under the procedure described in [Droop, 1987]. The formula amounts of ( $\mathrm{Na}+\mathrm{K})_{\mathrm{A}}$ were calculated according to [Leake, 1997].
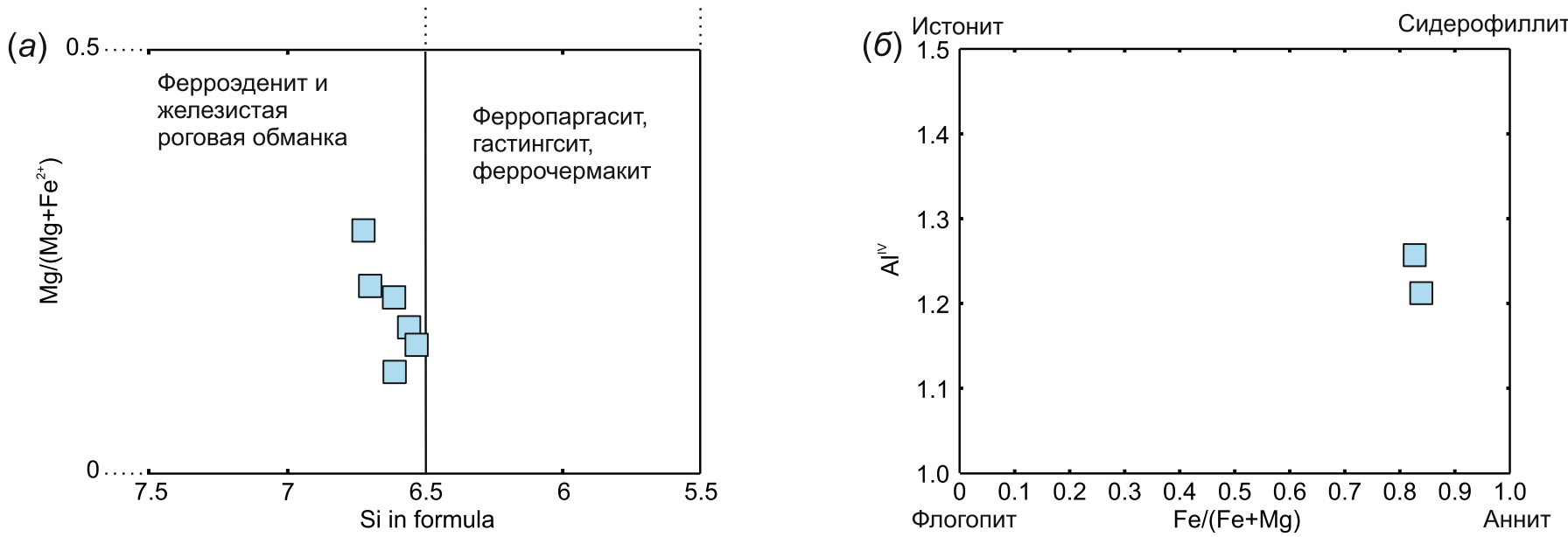

Рис. 4. Классификационные диаграммы $\mathrm{Mg} /\left(\mathrm{Mg}+\mathrm{Fe}^{2+}\right)$ - Si (модифицированная после [Leake, 1997]) для амфиболов (a) и $\mathrm{Al}^{\mathrm{IV}}-\mathrm{Fe} /(\mathrm{Fe}+\mathrm{Mg})$ для биотитов (б) из гранитоидов Татарниковского массива.

Fig. 4. Classification diagrams: $\mathrm{Mg} /\left(\mathrm{Mg}+\mathrm{Fe}^{2+}\right)-\mathrm{Si}$ (modified after [Leake, 1997]) for amphiboles $(a)$, and $\mathrm{Al}{ }^{\mathrm{IV}}-\mathrm{Fe} /(\mathrm{Fe}+\mathrm{Mg})$ for biotites (б) from the Tatarnikovsky granitoids. 
T а 6 л и ц а 3 3. Представительные анализы биотитов и их кристаллохимические формулы

$\mathrm{T}$ a b l e 3. Representative analyses and crystallochemical formulas for biotite

\begin{tabular}{|c|c|c|}
\hline Образец & 0273 & 0273 \\
\hline Минерал & Bt_1 & Bt_2 \\
\hline $\mathrm{SiO}_{2}$ & 34.19 & 33.52 \\
\hline $\mathrm{TiO}_{2}$ & 1.73 & 1.77 \\
\hline $\mathrm{Al}_{2} \mathrm{O}_{3}$ & 14.60 & 15.01 \\
\hline $\mathrm{FeO}$ & 32.03 & 31.47 \\
\hline $\mathrm{MnO}$ & 0.30 & 0.26 \\
\hline MgO & 3.42 & 3.80 \\
\hline $\mathrm{CaO}$ & 0.04 & 0.07 \\
\hline $\mathrm{K}_{2} \mathrm{O}$ & 9.28 & 9.31 \\
\hline Сумма & 95.58 & 95.20 \\
\hline $\mathrm{Si}$ & 2.788 & 2.742 \\
\hline $\mathrm{Ti}$ & 0.106 & 0.109 \\
\hline $\mathrm{AllV}^{\mathrm{IV}}$ & 1.212 & 1.258 \\
\hline $\mathrm{AlVI}$ & 0.191 & 0.190 \\
\hline $\mathrm{Fe}$ & 2.184 & 2.154 \\
\hline $\mathrm{Mn}$ & 0.021 & 0.018 \\
\hline $\mathrm{Mg}$ & 0.415 & 0.463 \\
\hline $\mathrm{Ca}$ & 0.004 & 0.006 \\
\hline K & 0.965 & 0.972 \\
\hline Сумма & 7.887 & 7.911 \\
\hline $\mathrm{Fe} /(\mathrm{Fe}+\mathrm{Mg})$ & 0.84 & 0.82 \\
\hline
\end{tabular}

П р и м е ч а н и е. Расчет кристаллохимических формул проводился на 11 атомов кислорода.

$\mathrm{N}$ o t e. The crystallochemical formulas were calculated for 11 atoms of oxygen.

циями $\mathrm{Nb}(23-48$ г/т), Y (57-95 г/т), Zr (1058-1663 г/т - крупнозернистые гранитоиды, 702-765 г/т мелкозернистые), Ва (2156-2670 г/т - крупнозернистые, 1168-1343 г/т - мелкозернистые), а также пониженными содержаниями Sr (91-131 г/т). Все гранитоиды характеризуются фракционированным распределением РЗЭ $\left((\mathrm{La} / \mathrm{Yb})_{\mathrm{n}}=6.2-8.6\right)$ (рис. 6, $a)$, при этом для крупнозернистых гранитоидов фиксируется хорошо выраженная положительная $\mathrm{Eu}$ аномалия (Eu/Eu*=1.08-1.82) на спектрах рас-

Т а б л и ц а 4. Представительные анализы ильменитов и их кристаллохимические формулы

$\mathrm{T}$ a b l e 4. Representative analyses and crystallochemical formulas for ilmenite

\begin{tabular}{|c|c|c|c|}
\hline Образец & 0268 & 0270 & 0270 \\
\hline Минерал & Ilm_1 & Ilm_1 & Ilm_2 \\
\hline $\mathrm{SiO}_{2}$ & 0.64 & 0.00 & 0.00 \\
\hline $\mathrm{TiO}_{2}$ & 36.96 & 51.92 & 51.74 \\
\hline $\mathrm{Al}_{2} \mathrm{O}_{3}$ & 0.23 & 0.09 & 0.08 \\
\hline $\mathrm{Fe}_{2} \mathrm{O}_{3}$ & 28.33 & 0.00 & 1.61 \\
\hline $\mathrm{FeO}$ & 29.58 & 41.16 & 42.82 \\
\hline $\mathrm{MnO}$ & 3.58 & 3.58 & 3.50 \\
\hline $\mathrm{CaO}$ & 0.62 & 0.12 & 0.14 \\
\hline Сумма & 99.94 & 96.87 & 99.88 \\
\hline $\mathrm{Si}$ & 0.016 & 0.000 & 0.000 \\
\hline $\mathrm{Ti}$ & 0.709 & 1.011 & 0.983 \\
\hline $\mathrm{Al}$ & 0.007 & 0.003 & 0.002 \\
\hline $\mathrm{Fe}^{3+}$ & 0.543 & 0.000 & 0.031 \\
\hline $\mathrm{Fe}^{2+}$ & 0.631 & 0.891 & 0.905 \\
\hline $\mathrm{Mn}$ & 0.077 & 0.078 & 0.075 \\
\hline $\mathrm{Ca}$ & 0.017 & 0.003 & 0.004 \\
\hline Сумма & 2.000 & 1.987 & 2.000 \\
\hline
\end{tabular}

П р и м е ч а н и е. Расчет кристаллохимических формул проводился на три атома кислорода.

$\mathrm{N}$ o t e. The crystallochemical formulas were calculated for three atoms of oxygen. 
T.V. Donskaya et al.: Petrogenesis and structural position of the Early Proterozoic charnockites...

Т а б л и ц а 5 . Химический состав гранитоидов Татарниковского массива

$\mathrm{T}$ a b l e 5 . Chemical composition of the Tatarnikovsky granitoids

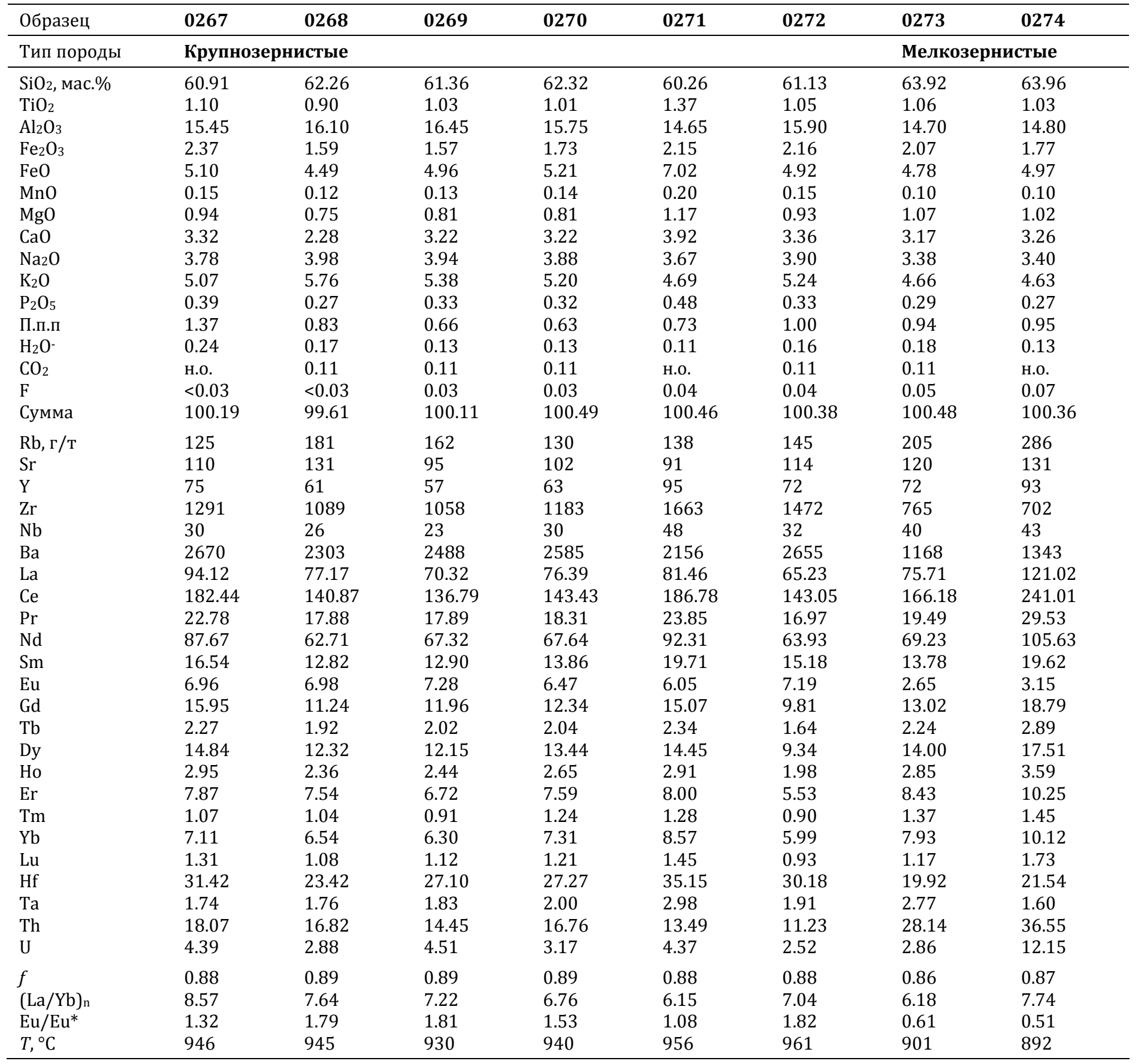

П р и м е ч а н и е. $f=\mathrm{FeO}^{*} /\left(\mathrm{FeO}^{*}+\mathrm{MgO}\right), \mathrm{FeO}^{*}=\mathrm{FeO}+0.8998 \times \mathrm{Fe}_{2} \mathrm{O}_{3} ; \mathrm{Eu} / \mathrm{Eu}^{*}=\mathrm{Eu}_{\mathrm{n}} / \sqrt{ }\left(\mathrm{Sm}_{\mathrm{n}} \times \mathrm{Gd}\right) ; \mathrm{n}-$ значения нормализованы по составу хондрита [Wakita et al., 1970]; $T,{ }^{\circ} \mathrm{C}$ - температуры насыщения расплава цирконом [Watson, Harrison, 1983].

$\mathrm{N}$ o t e. $f=\mathrm{FeO}^{*} /\left(\mathrm{FeO}^{*}+\mathrm{MgO}\right), \mathrm{FeO}^{*}=\mathrm{FeO}+0.8998 \times \mathrm{Fe}_{2} \mathrm{O}_{3} ; \mathrm{Eu} / \mathrm{Eu}^{*}=\mathrm{Eu}_{\mathrm{n}} / \sqrt{ }\left(\mathrm{Sm}_{\mathrm{n}} \times \mathrm{Gd}_{\mathrm{n}}\right) ; \mathrm{n}-$ values normalized to chondrite [Wakita et al., 1970$]$; $T,{ }^{\circ} \mathrm{C}$ - zircon saturation temperature [Watson, Harrison, 1983].

пределения РЗЭ (рис. 6, a), а для мелкозернистых гранитоидов отмечается отрицательная Eu аномалия (Eu/Eu*=0.51-0.61) (рис. 6, a). На мультиэлементных спектрах гранитоидов Татарниковского массива отмечаются отрицательные аномалии по $\mathrm{Nb}-\mathrm{Ta}, \mathrm{Sr}, \mathrm{P}, \mathrm{Ti}$, положительные аномалии по La-Ce и Zr-Hf (рис. 6, б). Различия между крупнозернисты- ми и мелкозернистыми разностями наблюдаются в спектрах несовместимых элементов, в частности $\mathrm{Rb}, \mathrm{Ba}, \mathrm{Th}, \mathrm{U}$ (рис. 6, б).

Химический состав чарнокитов Татарниковского массива позволяет сопоставлять их с гранитами А-типа [Whalen et al., 1987]. На диаграмме $\mathrm{FeO}^{*} / \mathrm{MgO}-(\mathrm{Ce}+\mathrm{Zr}+\mathrm{Nb}+\mathrm{Y})$ [Whalen et al., 1987] фигу- 

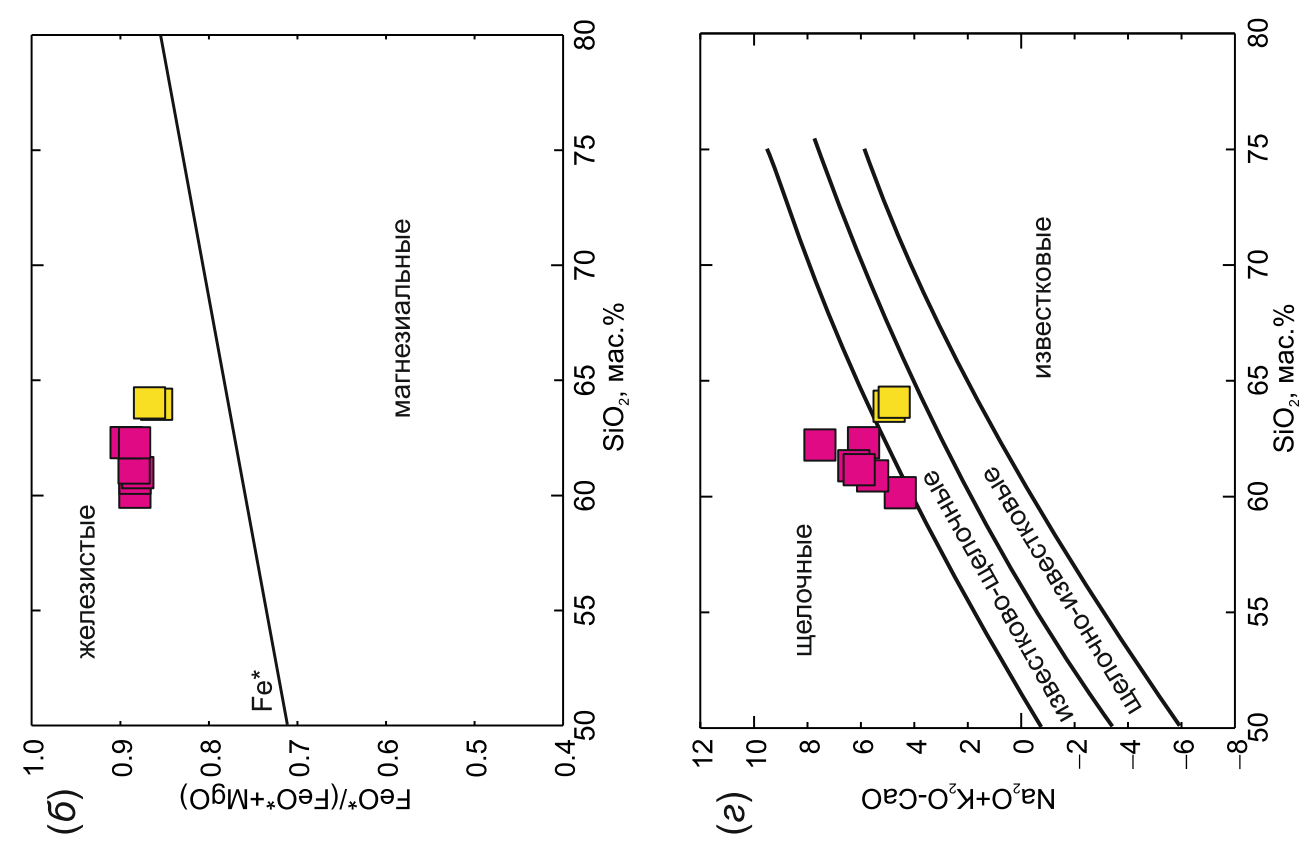

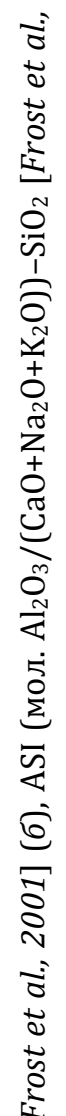

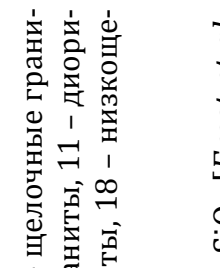

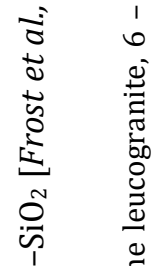

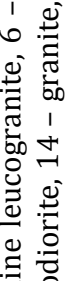

1
+

ఠิ

武

婿

ปั

1 壱

氙

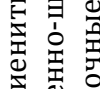

峁 卷

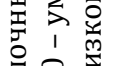

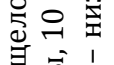

i

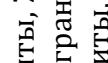

要壳

它

1 क⿺辶

เ 1 ก

ब न

氞芯

ชี

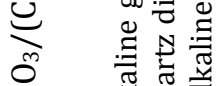

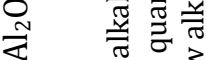

일 $\quad 113$

छ

$\overline{\mathrm{s}}$

के

ర్ర

6.

공

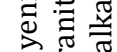

忿总袁

iั่

¿

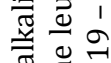

i 1.

ถุ

N

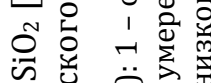

垔

$\stackrel{\square}{2}$
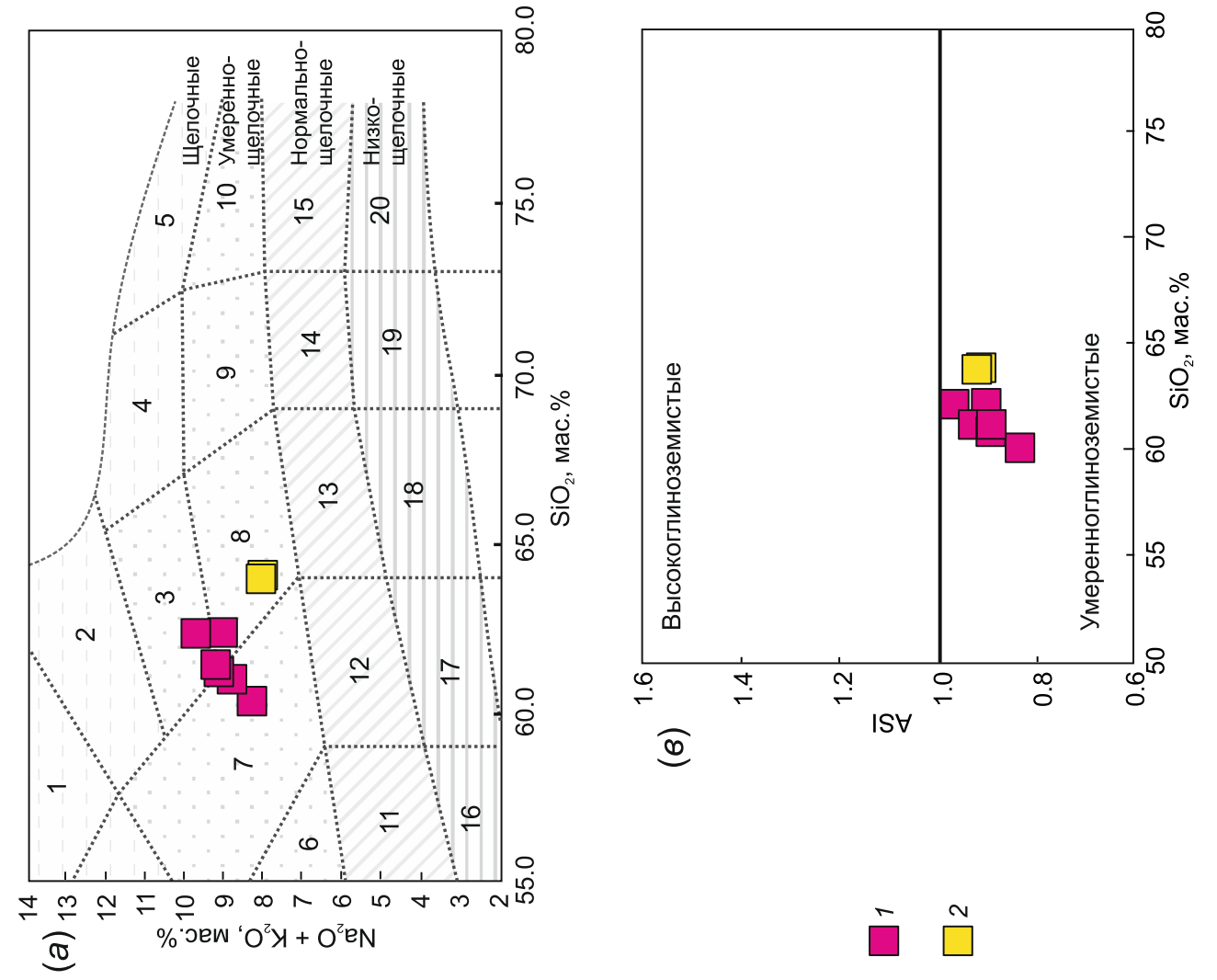

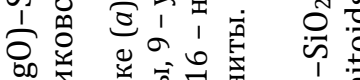

के 苟

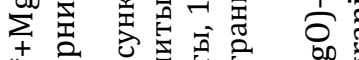

:

$\sum_{100}^{\infty} 00$

$+\frac{1}{4} 100$

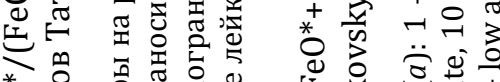

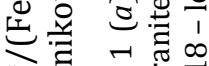

*

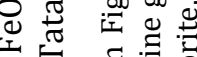

है⿴囗十

ก के है त

จิ

i்

๑๐

茫

๘ँ

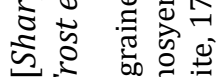

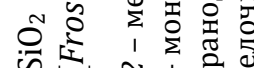

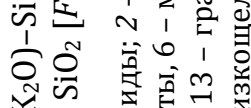

늘

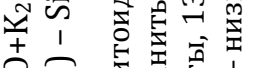

क 10.110

$\tau_{0} 1$ i $\infty$

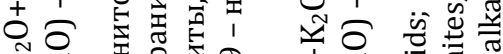

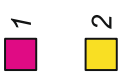

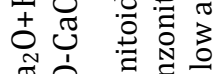

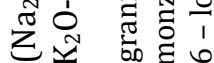

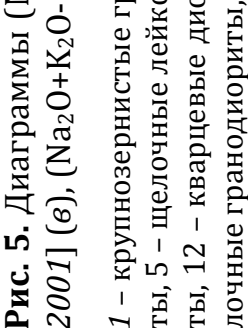

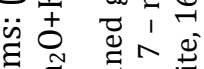

तี त्र ज्ञ

ప్ర

苟

ம்

ตำ 
T.V. Donskaya et al.: Petrogenesis and structural position of the Early Proterozoic charnockites...
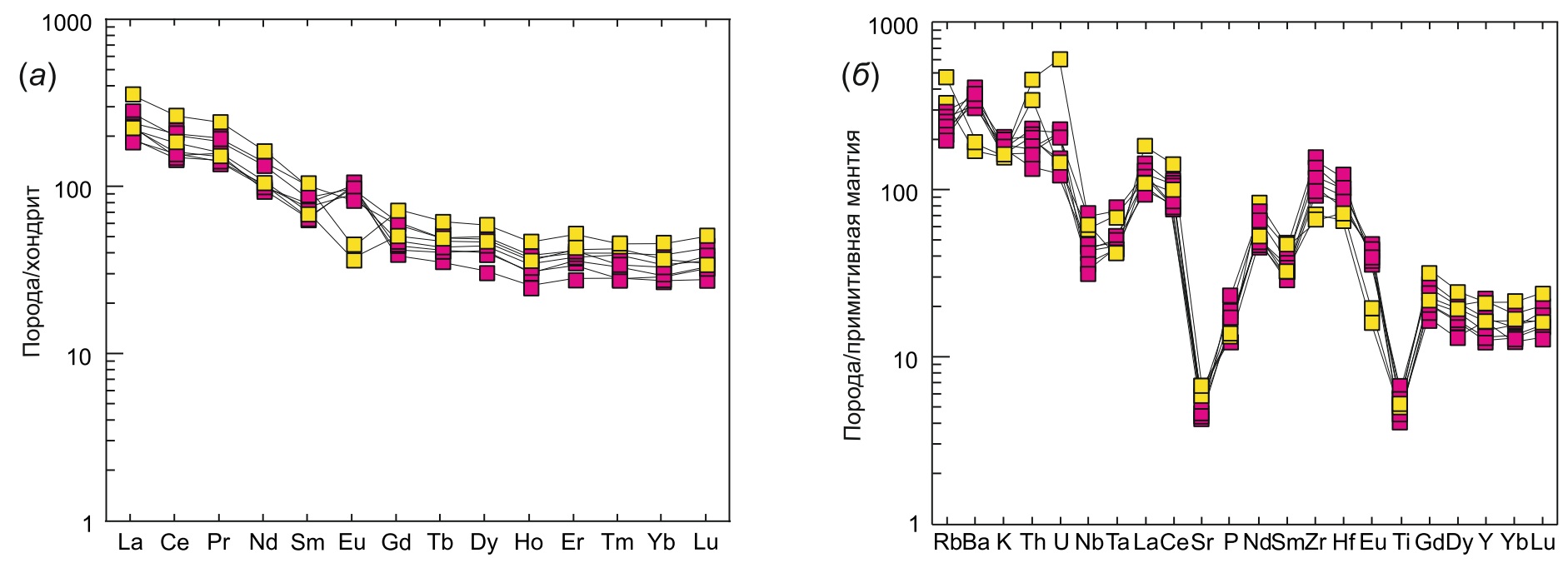

Рис. 6. Распределение редкоземельных и редких элементов в гранитоидах Татарниковского массива. Содержания элементов нормализованы к хондриту [Wakita et al., 1970] (a) и примитивной мантии [Sun, McDonough, 1989] (б). Условные обозначения см. рис. 5.

Fig. 6. Distribution of rare-earth and rare elements in the Tatarnikovsky granitoids. The concentration values are normalized to chondrite [Wakita et al., 1970] (a) and the primitive mantle [Sun, McDonough, 1989] (б). See the legend in Fig. 5.

ративные точки гранитоидов попадают в поле гранитов А-типа (рис. 7, a), а на диаграмме $\mathrm{CaO} /\left(\mathrm{FeO}^{*}++\mathrm{MgO}+\mathrm{TiO}_{2}\right)-\mathrm{Al}_{2} \mathrm{O}_{3}$ [Dall'Agnol, Oliveira, 2007] либо располагаются в поле гранитов А-типа, либо находятся в непосредственной близости от этого поля (рис. 7, б). На диаграмме $\mathrm{Rb}-(\mathrm{Y}+\mathrm{Nb})$ [Pearce, 1996] точки составов большинства чарно- китов попадают в поле постколлизионных гранитов (рис. 8).

Проанализированные гранитоиды Татарниковского массива характеризуются незначительными отрицательными величинами $\varepsilon \mathrm{Nd}(\mathrm{T})=-1.4 \ldots-3.5$ и модельным возрастом $\mathrm{T}_{\mathrm{Nd}} \mathrm{DM}=2.4-2.5$ млрд лет (табл. 6) [Gladkochub et al., 2009]. (a)

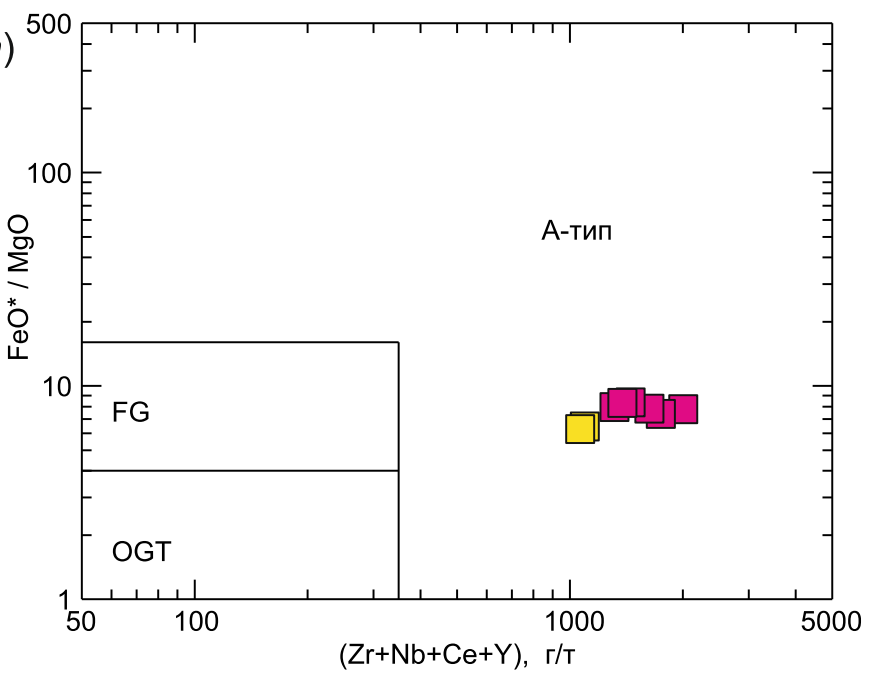

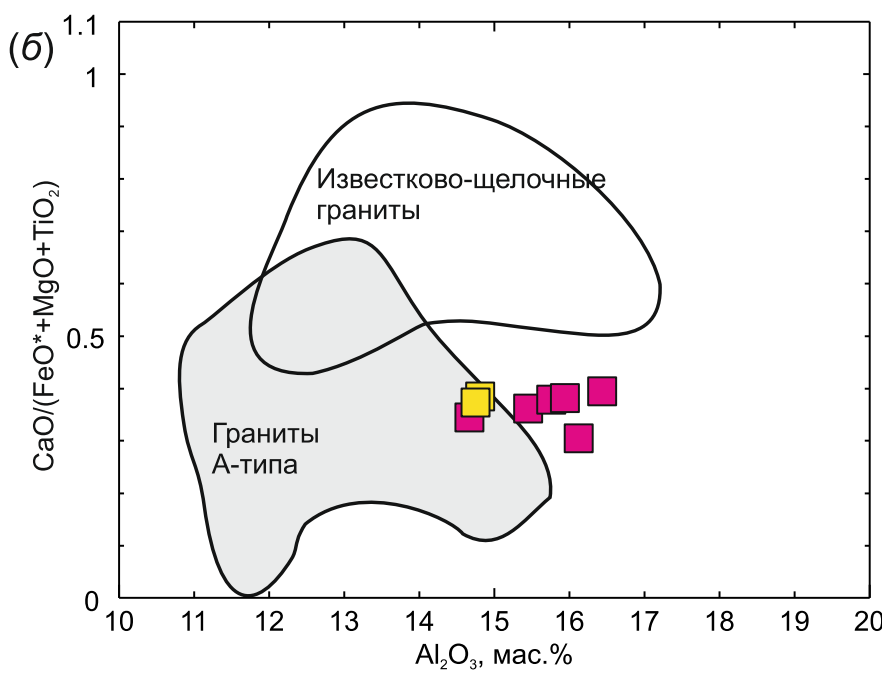

Рис. 7. Диаграммы $\mathrm{FeO}^{*} / \mathrm{MgO}-(\mathrm{Ce}+\mathrm{Zr}+\mathrm{Nb}+\mathrm{Y})$ [Whalen et al., 1987] (a) и $\mathrm{CaO} /\left(\mathrm{FeO}^{*}+\mathrm{MgO}^{2} \mathrm{TiO}_{2}\right)-\mathrm{Al}_{2} \mathrm{O}_{3}$ [Dall'Agnol, Oliveira, 2007] (б) для гранитоидов Татарниковского массива. Условные обозначения см. рис. 5.

Fig. 7. Diagrams: $\mathrm{FeO}^{*} / \mathrm{MgO}-(\mathrm{Ce}+\mathrm{Zr}+\mathrm{Nb}+\mathrm{Y})$ [Whalen et al., 1987] (a), and $\mathrm{CaO} /\left(\mathrm{FeO}^{*}+\mathrm{MgO}+\mathrm{TiO}_{2}\right)-\mathrm{Al}_{2} \mathrm{O}_{3}[$ Dall'Agnol, Oliveira, 2007] (б) for the Tatarnikovsky granitoids. See the legend in Fig. 5. 


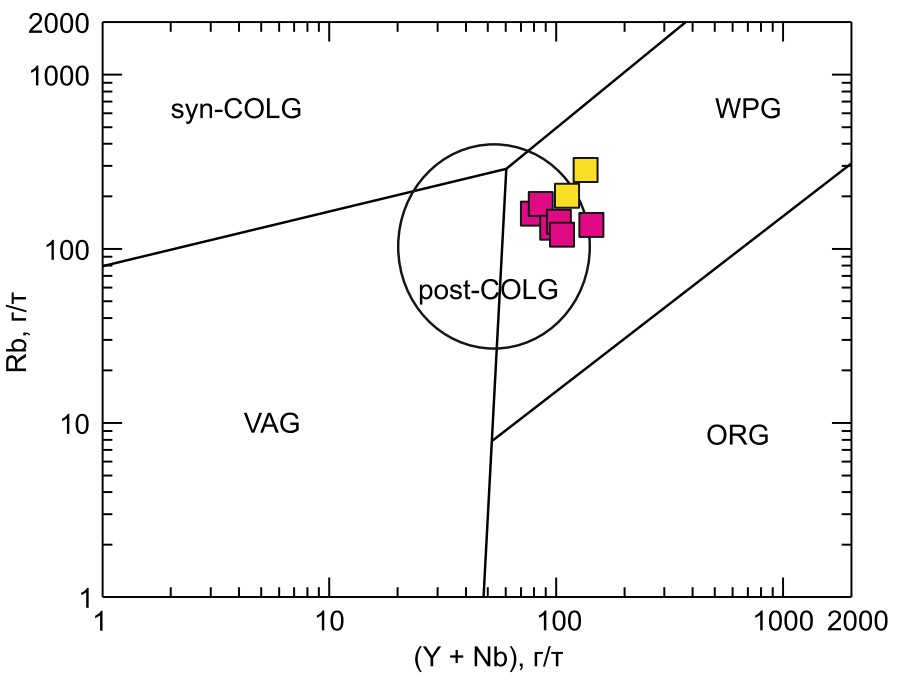

\section{7. Дискуссия}

\section{1. ПЕТРОГЕНЕЗИС ГРАНИТОИДОВ}

\subsection{1. Условия кристаллизации гранитоидных расплавов}

Температура. Приблизительная оценка температур начальных стадий кристаллизации родоначальных для гранитоидов Татарниковского массива расплавов была проведена на основе цирконового термометра Е.Б. Ватсона и Т.М. Харрисона [Watson, Harrison, 1983], фиксирующего степень насыщения расплава цирконом в зависимости от температуры и состава этого расплава. Проведенные расчеты показали, что для крупнозернистых гранитоидов фиксируются температуры $930-960{ }^{\circ} \mathrm{C}$, а для мелкозернистых порфировидных разностей 890-900 ${ }^{\circ} \mathrm{C}$ (см. табл. 5).

Давления. Были рассчитаны давления, существующие при кристаллизации гранитоидных расплавов с использованием амфиболового геобарометра М. Джонсона и М. Рузерфорда Uohnson, Rutherford, 1989]. В результате проведенных расчетов были зафиксированы давления 2.2-2.9 кбар, близкие давлениям, полученным для гранитоидов ирельского комплекса [Donskaya et al., 2005], что свиде-
Рис. 8. Диаграмма Rb - (Y+Nb) [Pearce, 1996] для гранитоидов Татарниковского массива. Условные обозначения см. рис. 5. VAG - граниты вулканических дуг, ORG - граниты океанических хребтов, WPG - внутриконтинентальные граниты, syn-COLG - синколлизионные граниты, post-COLG - постколлизионные граниты.

Fig. 8. Diagram $\mathrm{Rb}-(\mathrm{Y}+\mathrm{Nb})$ [Pearce, 1996] for the Tatarnikovsky granitoids. See the legend in Fig. 5. VAG - volcanic-arc granites, ORG - oceanic-ridge granites, WPG within-plate granites, syn-COLG - syn-collisional granites, post-COLG - post-collisional granites. тельствует о кристаллизации гранитоидных расплавов в гипабиссальных условиях.

Фугитивность кислорода $\left(\mathrm{fO}_{2}\right)$. Качественная оценка фугитивности кислорода в гранитоидах Татарниковского массива была выполнена на основании анализа составов Fe-Ti окислов и амфиболов в исследуемых породах. Наличие ильменита как единственного Fe-Ti окисла в гранитоидах свидетельствует о низких значениях $\mathrm{fO}_{2}$ [Ishihara, 1977], что может указывать на кристаллизацию в условиях, когда величина $\mathrm{fO}_{2}$ соответствовала (или была ниже) QFM буфера [Anderson, 1996]. Амфиболы в гранитоидах Татарниковского массива характеризуются достаточно высокими значениями отношения $\mathrm{Fe}^{2+} /\left(\mathrm{Mg}^{2} \mathrm{Fe}^{2+}\right)=0.72-0.88$, которые возможны при кристаллизации в условиях низкой или умеренной фугитивности кислорода (рис. 9) [Anderson, Smith, 1995].

\subsection{2. Источники гранитоидов и особенности их выплавления}

Как уже было отмечено, по своим геохимическим характеристикам гранитоиды Татарниковского массива соответствуют гранитам А-типа [Whalen et al., 1987], а на основании присутствия в них ортопироксена могут быть отнесены к группе

T а б л и ц а $6 . \mathrm{Sm}-\mathrm{Nd}$ изотопные данные для гранитоидов Татарниковского массива [Gladkochub et al., 2009]

T a b l e 6. Sm-Nd isotopic data for the Tatarnikovsky granitoids [Gladkochub et al., 2009]

\begin{tabular}{|c|c|c|c|c|c|c|c|c|}
\hline \multirow[t]{2}{*}{$\begin{array}{l}\text { Номер } \\
\text { образца }\end{array}$} & \multirow[t]{2}{*}{$\begin{array}{l}\text { Возраст, } \\
\text { млн лет }\end{array}$} & \multicolumn{2}{|c|}{$\begin{array}{l}\text { Содержание, } \\
\text { ppm }\end{array}$} & \multirow[t]{2}{*}{${ }^{147} \mathrm{Sm} /{ }^{144} \mathrm{Nd}$} & \multirow[t]{2}{*}{${ }^{143} \mathrm{Nd} /{ }^{144} \mathrm{Nd} \pm 2 \sigma$} & \multirow[t]{2}{*}{$\varepsilon_{\mathrm{Nd}}(\mathrm{t})$} & \multirow[t]{2}{*}{$\begin{array}{l}\mathrm{t}_{\mathrm{Nd}}(\mathrm{DM}), \\
\text { млн лет }\end{array}$} & \multirow[t]{2}{*}{$\begin{array}{l}\mathrm{t}_{\mathrm{Nd}}(\mathrm{DM}-2 \mathrm{st}), \\
\text { млн лет }\end{array}$} \\
\hline & & $\mathrm{Sm}$ & $\mathrm{Nd}$ & & & & & \\
\hline 0268 & 1850 & 11.99 & 62.90 & 0.1152 & $0.511575 \pm 31$ & -1.4 & 2430 & 2460 \\
\hline 0270 & 1850 & 11.53 & 58.74 & 0.1186 & $0.511510 \pm 56$ & -3.5 & 2620 & 2631 \\
\hline
\end{tabular}




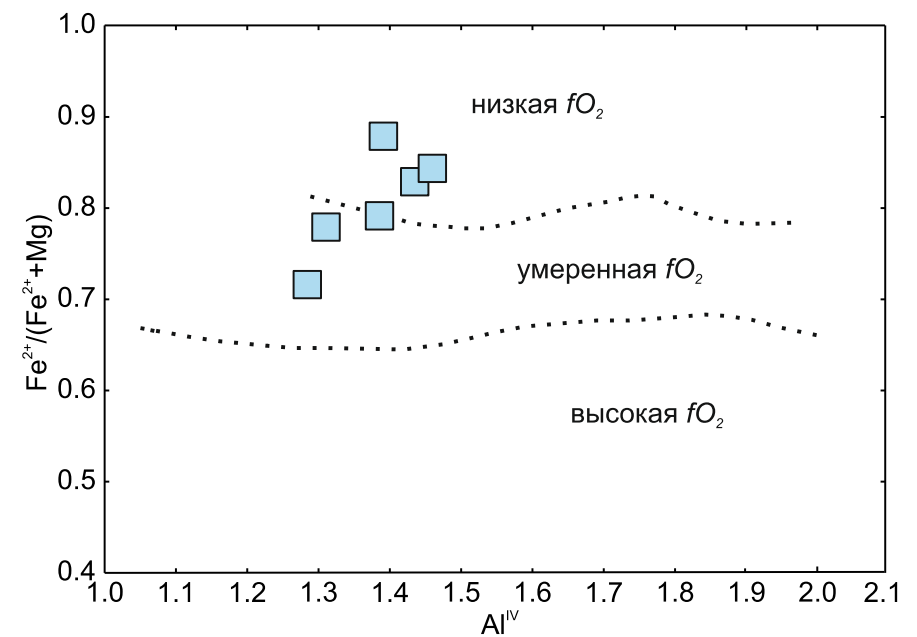

Рис. 9. Классификационная диаграмма $\mathrm{Fe}^{2+} /\left(\mathrm{Fe}^{2++}\right.$ $+\mathrm{Mg})-\mathrm{Al}{ }^{\mathrm{V}}$ [Anderson, Smith, 1995] для амфиболов из гранитоидов Татарниковского массива.

Fig. 9. Classification diagram $\mathrm{Fe}^{2+} /\left(\mathrm{Fe}^{2+}+\mathrm{Mg}\right)-\mathrm{Al}^{\mathrm{IV}}$ [Anderson, Smith, 1995] for amphiboles from the Tatarnikovsky granitoids.

чарнокитов [Frost B.R., Frost C.D., 2008]. Гранитоиды Татарниковского массива характеризуются высокой железистостью $\left(\mathrm{FeO}^{*} /\left(\mathrm{FeO}^{*}+\mathrm{MgO}\right)==0.86-0.89\right)$ и в совокупности с другими петрохимическими характеристиками обнаруживают сходство с щелочными и известково-щелочными умеренно-глиноземистыми железистыми гранитами [Frost C.D., Frost B.R., 2011]. Для гранитоидов такого состава предполагается формирование в результате фракционной кристаллизации или частичного плавления толеитовых базальтов или их дифференциатов [Loiselle, Wones, 1979; Frost C.D., Frost B.R., 1997, 2011]. Подобный источник для гранитоидов Татарниковского массива подтверждается высокой железистостью амфиболов и биотитов в этих породах (см. рис. 4), а также низкой или умеренной фугитивностью кислорода (рис. 9). В то же время чарнокиты Татарниковского массива обнаруживают отрицательные значения $\varepsilon_{\mathrm{Nd}}$, равные $-1.4 \ldots-3.5$ (см. табл. 6), а их фигуративные точки располагаются на диаграмме $\mathrm{Y}-\mathrm{Nb}-\mathrm{Ce}[E b y, 1992]$ в поле $\mathrm{A}_{2}$ (рис. 10), т.е. в поле гранитов, сформированных в результате плавления пород континентальной коры или в результате взаимодействия мантийных расплавов с материалом континентальной коры. Таким образом, маловероятно, что в качестве источника для чарнокитов Татарниковского массива, а также для других массивов татарниковского комплекса служил ювенильный мантийный материал. Однако предлагаемая ниже петрогенетическая модель все же связана с внедрением мантийных магм в основание коры. На основании минералогических и геохимических характеристик гранитоидов Татарниковского массива можно допустить, что наиболее вероятным источником этих пород являлись мафические породы нижней коры (габброиды, ферродиориты), которые могли быть сформированы в результате дифференциации мантийных толеитовых магм, внедрившихся в основание континентальной коры. Подобный источник для гранитоидов (чарнокитов) батолита Шерман (Sherman batholith), с которыми по многим своим характеристикам обнаруживают сходство чарнокиты Татарниковского массива, предполагали К. Фрост с соавторами [Frost et al., 1999]. В настоящее время невозможно точно установить, когда именно произошло внедрение толеитовых магм в основание коры и их преобразование в габброиды нижней коры. Возможно, андерплейтинг базитовых расплавов к основанию коры имел место в процессе формирования аккреционного орогена над погружающейся зоной субдукции, когда были сформированы гранитоиды чуйского и кутимского комплекса Чуйского блока с возрастом около 2.02 млрд лет,

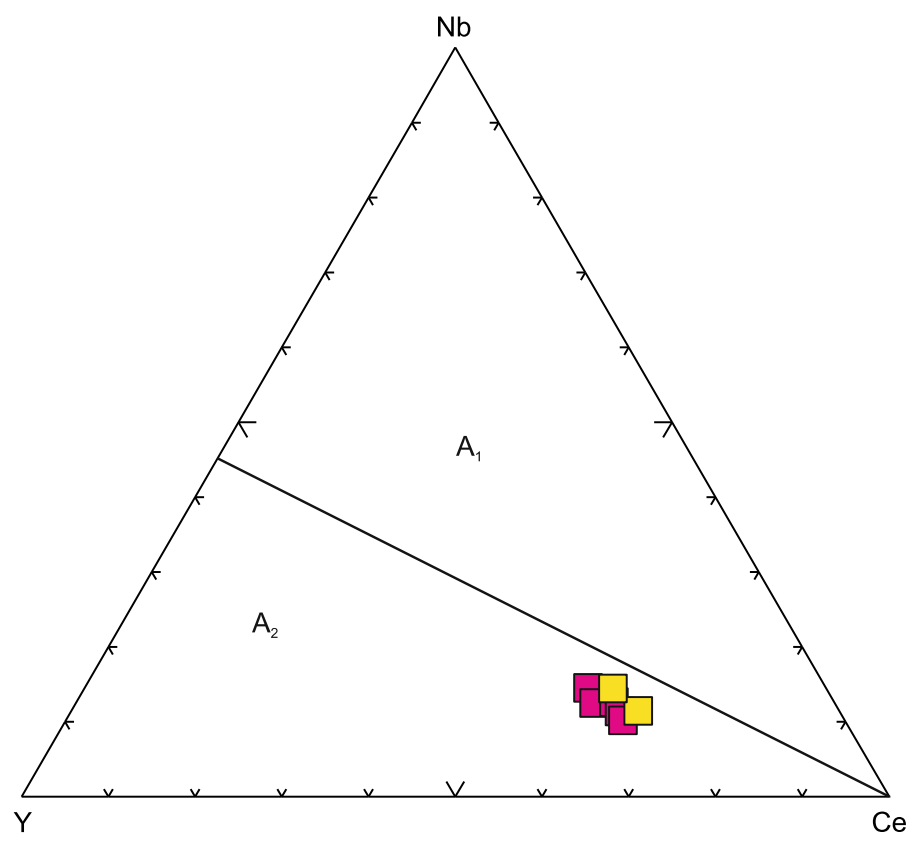

Рис. 10. Диаграмма Y-Nb-Ce [Eby, 1992] для гранитоидов Татарниковского массива. Условные обозначения см. рис. 5. А - поле гранитоидов, источниками которых являлись породы, по своему составу подобные базальтам океанических островов; $A_{2}$ - поле гранитоидов, источниками которых являлись породы континентальной коры.

Fig. 10. Diagram Y-Nb-Ce [Eby, 1992] for the Tatarnikovsky granitoids. See the legend in Fig. 5. $A_{1}-$ field of granitoids, the sources of which were rocks similar in composition to oceanic-island basalts; $A_{2}$ - field of granitoids, the sources of which were continental crust rocks. 
что мы предполагали ранее [Donskaya et al., 2013b]. C такой же долей вероятности можно предположить, что андерплейдинг базальтовых расплавов и их преобразование в породы нижней коры произошли на стадии утолщения коры в процессе коллизии. Также на основании анализа геологической ситуации в регионе, а именно того факта, что одновременно с формированием гранитоидов татарниковского комплекса в южной части Северо-Байкальского вулканического пояса произошло внедрение комбинированных даек, одним из компонентов которых являются долериты, по составу соответствующие высокожелезистым толеитам [Shokhonova et al., 2010], можно предположить, что внедрение мантийных толеитовых магм в основание коры и их дифференциация с образованием габброидов могли иметь место непосредственно перед внедрением гранитоидов Татарниковского массива. В любом случае, в районе распространения чарнокитов татарниковского комплекса имеются все предпосылки для присутствия в основании нижней коры пород основного состава (габброидов, ферродиоритов), которые и послужили источником для данных гранитоидов. Также следует отметить, что формирование расплавов с геохимическими характеристиками гранитов А-типа в результате дифференциации или частичного плавления ферродиоритов подтверждено экспериментальными работами [Scoates et al., 1996]. Высокие температуры насыщения расплава цирконом [Watson, Harrison, 1983], рассчитанные для крупнозернистых гранитоидов Татарниковского массива, - 930-960 ${ }^{\circ} \mathrm{C}$, показали, что формирование гранитоидных расплавов происходило в условиях нижней коры при температурах, соответствующих образованию классических гранитов А-типа [Creaser, White, 1991; Skjerlie, Johnston, 1993]. Высокие температуры свидетельствуют также и о высокой растворимости акцессорных фаз, способствующей значительному обогащению расплавов высокозарядными элементами, что подтверждается высокими содержаниями $\mathrm{Zr}, \mathrm{Nb}, \mathrm{Y}, \mathrm{REE}$ в гранитоидах Татарниковского массива (см. табл. 5). Высокая железистость амфиболов и биотитов в гранитоидах, присутствие ильменита как единственного Fe-Ti оксида, низкая или умеренная фугитивность кислорода указывают на кристаллизацию гранитоидов из сухих (маловодных) расплавов. Что касается кристаллизации расплавов, радоначальных для гранитоидов Татарниковского массива, то она происходила в гипабиссальных условиях, о чем свидетельствуют достаточно низкие давления (2.2-2.9 кбар), рассчитанные для гранитоидов с использованием амфиболового геобарометра [Johnson, Rutherford, 1989].

Высокие концентрации Ва и положительные Eu аномалии на спектрах распределения редкозе- мельных элементов крупнозернистых гранитоидов (см. рис. 6, $a$, б) позволяют предполагать, что процесс частичного плавления базитового источника был наиболее предпочтительным при формировании этих пород. Что касается мелкозернистых порфировых гранитоидов, то они обнаруживают более высокие содержания кремнезема и существенно более низкие содержания $\mathrm{Ba}, \mathrm{Zr}$ по сравнению с крупнозернистыми разностями (см. табл. 5), а также отрицательные Еu аномалии на спектрах распределения РЗЭ (см. рис. 6, a), поэтому процесс фракционной кристаллизации гранитоидного расплава принимается в качестве основного при формировании этих наиболее дифференцированных разностей.

\section{2. ТЕКТОНИЧЕСКАЯ ОБСТАНОВКА ФОРМИРОВАНИЯ ГРАНИТОИДОВ}

Тектоническая позиция становления чарнокитов татарниковского комплекса тесно сопряжена с условиями формирования Северо-Байкальского вулканоплутонического пояса, с породами которого гранитоиды татарниковского комплекса находятся в тесной пространственной связи. Кроме того, как мы уже отмечали, возраст чарнокитов татарниковского комплекса совпадает с возрастом наиболее молодых образований Северо-Байкальского вулканоплутонического пояса (1.85-1.84 млрд лет), но при этом является более молодым по сравнению с возрастом большинства пород акитканской серии и гранитоидов ирельского комплекса (1.88-1.86 млрд лет). Предполагается, что становление СевероБайкальского вулканоплутонического пояса осуществлялось в режиме растяжения, в котором обособляются два импульса магматизма (1.88-1.86 и 1.85-1.84 млрд лет), разделенные периодом усиления растяжения с формированием динамометаморфизованных пород, проявившимся на рубеже 1.86-1.85 млрд лет. Таким образом, этот период динамометаморфизма и собственно формирование Даванской зоны смятия связаны с наиболее интенсивной стадией процессов внутриконтинентального растяжения в данном регионе в раннепротерозойский период. Динамометаморфизм варьируется от зеленосланцевой до амфиболитовой фации, при этом проявления высокой степени метаморфизма тяготеют к зонам разрывных нарушений, где породы подвержены динамометаморфизму и метасоматозу. Наиболее интенсивно эти процессы проявились именно в Даванской зоне смятия, расположенной между Кунерминским и Левоминским разломами. Гранитоиды татарниковского комплекса, тяготеющие к Даванской зоне смятия, не подвержены динамометаморфизму, что также указывает на то, что их становление происходило на заключитель- 
ных стадиях формирования Северо-Байкальского вулканоплутонического пояса.

На основании оценки возраста и тектонической позиции гранитоиды татарниковского комплекса были включены в структуру Южно-Сибирского постколлизионного магматического пояса, который прослеживается вдоль всего южного края Сибирского кратона [Larin et al., 2003, 2009], поэтому в глобальном масштабе становления единой структуры Сибирского кратона геодинамическая обстановка формирования чарнокитов татарниковского комплекса рассматривается как постколлизионное растяжение. В то же время надо иметь в виду, что геодинамическая обстановка формирования гранитов контролируется и условиями образования расплавов. Для железистых известково-щелочных и щелочных умеренно-глиноземистых чарнокитов в качестве наиболее благоприятной обстановки формирования принимается обстановка внутриконтинентального рифтогенеза [Frost et al., 1999; Frost B.R., Frost C.D., 2008]. Полученные в последние годы новые данные о возрасте завершения коллизионных событий в той части Сибирского кратона, где распространены чарнокиты татарниковского комплекса, позволили снять противоречия в интерпретации геодинамической обстановки их формирования (постколлизионное растяжение или внутриконтинентальный рифтогенез). Гранитоиды татарниковского комплекса, так же как и входящие вместе с ними в структуру Южно-Сибирского магматического пояса породы Северо-Байкальского вулканоплутонического пояса, рапакивиподобные граниты приморского комплекса и гранитоиды абчадского комплекса, пересекают породы Акитканского складчатого пояса, выделенного О.М. Розеном [Rosen et al., 1994; Rosen, 2003]. В нашей работе [Donskaya et al., 2016] было показано, что основные коллизионные события в пределах Акитканского складчатого пояса завершились на временном рубеже 1.98-1.97 млрд лет, т.е. приблизительно на 100 млн лет ранее, чем началось формирование перечисленных выше пород, входящих в Южно-Сибирский постколлизионный магматический пояс, в том числе и гранитоидов татарниковского комплекса. Таким образом, можно сделать вывод о том, что формирование чарнокитов татарниковского комплекса, так же как и пород Северо-Байкальского вулканоплутонического пояса, гранитоидов приморского и абчадского комплексов, в локальном масштабе происходило в обстановке внутриконтинентального рифтогенеза, которая наиболее благоприятна для формирования пород, близких по составу гранитам А-типа. В масштабе же всего Сибирского кратона, как мы уже отмечали, обстановка формирования гранитоидов татарниковского комплекса на основании принадлежности их Южно-
Сибирскому постколлизионному магматическому поясу принимается как постколлизионная.

\section{8. ЗАКЛЮЧЕНИЕ}

Массивы чарнокитов татарниковского комплекса приурочены к Даванской зоне смятия северной части Байкальского краевого выступа фундамента Сибирского кратона, однако они не подвержены динамометаморфизму, милонитизации и метасоматозу, что указывает на их формирование после становления Даванской зоны. Возраст чарнокитов татарниковского комплекса (1.85 млрд лет) совпадает с возрастом наиболее молодых образований Северо-Байкальского вулканоплутонического пояса (1.85-1.84 млрд лет).

Чарнокиты татарниковского комплекса по составу близки щелочным и известково-щелочным умеренно-глиноземистым железистым гранитам. По своим геохимическим характеристикам чарнокиты соответствуют гранитам А-типа.

Оценка температур начальных стадий кристаллизации гранитоидных расплавов показала, что формирование чарнокитов происходило при высоких температурах $-890-960^{\circ} \mathrm{C}$ (температура насыщения расплава цирконом). Кристаллизация гранитоидных расплавов осуществлялась в гипабиссальных условиях при давлении 2.2-2.9 кбар, а также в условиях низкой или умеренной фугитивности кислорода.

Минералогические и геохимические данные свидетельствуют о том, что чарнокиты татарниковского комплекса могли быть образованы за счет плавления мафических пород нижней коры (габброидов, ферродиоритов), которые были сформированы в результате дифференциации мантийных толеитовых магм, внедрившихся в основание континентальной коры. Коровый источник чарнокитов подтверждается изотопным составом $\mathrm{Nd}$. Чарнокиты характеризуются отрицательными значениями $\varepsilon_{\mathrm{Nd}}(\mathrm{t})=-1.4 \ldots-3.5$.

Гранитоиды татарниковского комплекса входят в структуру Южно-Сибирского постколлизионного магматического пояса, прослеживающегося вдоль всего южного фланга Сибирского кратона, но при этом в локальном масштабе Байкальского краевого выступа фундамента кратона их формирование осуществлялось в обстановке внутриконтинентального рифтогенеза.

\section{9. БЛАГОДАРНОСТИ}

Работа выполнена при частичной поддержке РФФИ (проект № 18-05-00764). 


\section{0. ЛИТЕРАTУРA / REFERENCES}

Aleksandrov V.K., 1990. Thrust Faults and Overthrusts of Baikal Region. Nauka, Novosibirsk, 102 p. (in Russian] [Александров В.К. Надвиги и шарьяжные структуры Прибайкалья. Новосибирск: Наука, 1990. 102 с.].

Anderson J.L., 1996. Status of thermobarometry in granitic batholiths. Transactions of the Royal Society of Edinburgh: Earth Sciences 87 (1-2), 125-138. https://doi.org/10.1130/0-8137-2315-9.125.

Anderson J.L., Smith D.R., 1995. The effects of temperature and $\mathrm{fO}_{2}$ on the Al-in-hornblende barometer. American Mineralogist 80 (5-6), 549-559. https://doi.org/10.2138/am-1995-5-614.

Creaser R.A., White A.J.R., 1991. Yardea dacite - large-volume, high-temperature felsic volcanism from the Middle Proterozoic of South Australia. Geology 19 (1), 48-51. https://doi.org/10.1130/0091-7613(1991)019<0048:YDLVHT> 2.3.CO;2.

Dall'Agnol R., Oliveira D.C., 2007. Oxidized, magnetite-series, rapakivi-type granites of Carajás, Brazil: implications for classification and petrogenesis of $A$-type granites. Lithos 93 (3-4), 215-233. https://doi.org/10.1016/j.lithos 2006.03.065.

Didenko A.N., Vodovozov V.Y., Pisarevsky S.A., Gladkochub D.P., Donskaya T.V., Mazukabzov A.M., Stanevich A.M., Bibikova E.V., Kirnozova T.I., 2009. Palaeomagnetism and U-Pb dates of the Palaeoproterozoic Akitkan Group (South Siberia) and implications for pre-Neoproterozoic tectonics. In: S.M. Reddy, R. Mazumder, D.A.D. Evans, A.S. Collins (Eds.), Palaeoproterozoic supercontinents and global evolution. Geological Society, London, Special Publications, vol. 323, p. 145-163. https://doi.org/10.1144/SP323.7.

Donskaya T.V., Bibikova E.V., Gladkochub D.P., Mazukabzov A.M., Bayanova T.B., De Waele B., Bukharov A.A., Kirnozova T.I., 2008. Petrogenesis and age of the felsic volcanic rocks from the North Baikal volcanoplutonic belt, Siberian craton. Petrology 16 (5), 422-447. https://doi.org/10.1134/S0869591108050020.

Donskaya T.V., Bibikova E.V., Mazukabzov A.M., Kozakov I.K., Gladkochub D.P., Kirnozova T.I., Plotkina Yu.V., Reznitsky L.Z., 2003. The Primorsky granitoid complex of western Cisbaikalia: geochronology and geodynamic typification. Geologiya i Geofizika (Russian Geology and Geophysics) 44 (10), 968-979.

Donskaya T.V., Gladkochub D.P., Kovach V.P., Mazukabzov A.M., 2005. Petrogenesis of Early Proterozoic postcollisional granitoids in the southern Siberian craton. Petrology 13 (3), 229-252.

Donskaya T.V., Gladkochub D.P., Mazukabzov A.M., 2013a. Palaeoproterozoic granitoids of the Siberian craton: geochemical features and tectonic interpretation. In: Precambrian evolution and deep exploration of the continental lithosphere (7-9 October, 2013, Beijing, China). Abstract Volume. IAGR Conference Series № 15, p. 36-38.

Donskaya T.V., Gladkochub D.P., Mazukabzov A.M., Lepekhina E.N., 2016. Age and sources of the Paleoproterozoic premetamorphic granitoids of the Goloustnaya block of the Siberian craton: Geodynamic applications. Petrology 24 (6), 543-561. https://doi.org/10.1134/S0869591116050040.

Donskaya T.V., Gladkochub D.P., Mazukabzov A.M., Presnyakov S.L., Bayanova T.B., 2013b. Paleoproterozoic granitoids of the Chuya and Kutima complexes (southern Siberian craton): age, petrogenesis, and geodynamic setting. Russian Geology and Geophysics 54 (3), 283-296. https://doi.org/10.1016/j.rgg.2013.02.004.

Donskaya T.V., Gladkochub D.P., Mazukabzov A.M., Wingate M.T.D., 2014. Early Proterozoic postcollisional granitoids of the Biryusa block of the Siberian craton. Russian Geology and Geophysics 55 (7), 812-823. https://doi.org/ 10.1016/j.rgg.2014.06.002.

Donskaya T.V., Mazukabzov A.M., Bibikova E.V., Gladkochub D.P., Didenko A.N., Kirnozova T.I., Vodovozov V.Yu., Stanevich A.M., 2007. Stratotype of the Chaya Formation of the Akitkan Group in the North Baikal volcanoplutonic belt: age and time of sedimentation. Russian Geology and Geophysics 48 (9), 707-710. https://doi.org/10.1016/j.rgg. 2007.08.001.

Donskaya T.V., Sal'nikova E.B., Sklyarov E.V., Gladkochub D.P., Mazukabzov A.M., Kovach V.P., Yakovleva S.Z., Berezhnaya N.G., 2002. Early Proterozoic postcollision magmatism at the southern flank of the Siberian craton: new geochronological data and geodynamic implications. Doklady Earth Sciences 383 (2), 125-128.

Droop G.T.R., 1987. A general equation for estimating $\mathrm{Fe}^{3+}$ concentrations in ferromagnesian silicates and oxides from microprobe analyses, using stoichometric criteria. Mineralogical Magazine 51, 431-435.

Eby G.N., 1992. Chemical subdivision of the A-type granitoids: Petrogenetic and tectonic implications. Geology 20 (7), 641-644. https://doi.org/10.1130/0091-7613(1992)020<0641:CSOTAT>2.3.CO;2.

Frost B.R., Barnes C.G., Collins W.J., Arculus R.J., Ellis D.J., Frost C.D., 2001. A geochemical classification for granitic rocks. Journal of Petrology 42 (11), 2033-2048. https://doi.org/10.1093/petrology/42.11.2033.

Frost B.R., Frost C.D., 2008. On charnockites. Gondwana Research 13 (1) 2008, 30-44. https://doi.org/10.1016/j.gr 2007.07.006.

Frost C.D., Frost B.R., 1997. Reduced rapakivi-type granites: The tholeiite connection. Geology 25 (7), 647-650. https://doi.org/10.1130/0091-7613(1997)025<0647:RRTGTT>2.3.C0;2.

Frost C.D., Frost B.R., 2011. On ferroan (A-type) granitoids: their compositional variability and modes of origin. Journal of Petrology 52 (1), 39-53. https://doi.org/10.1093/petrology/egq070.

Frost C.D., Frost B.R., Chamberlain K.R., Edwards B.R., 1999. Petrogenesis of the 1.43 Ga Sherman batholith, SE Wyoming: a reduced rapakivi-type anorogenic granite. Journal of Petrology 40 (12), 1771-1802. https://doi.org/ 10.1093/petroj/40.12.1771. 
T.V. Donskaya et al.: Petrogenesis and structural position of the Early Proterozoic charnockites...

Gladkochub D.P., Donskaya T.V., Reddy S.M., Poller U., Bayanova T.B., Mazukabzov A.M., Dril S., Todt W., Pisarevsky S.A., 2009. Palaeoproterozoic to Eoarchaean crustal growth in southern Siberia: a Nd-isotope synthesis. In: S.M. Reddy, R. Mazumder, D.A.D. Evans, A.S. Collins (Eds.), Palaeoproterozoic supercontinents and global evolution. Geological Society, London, Special Publications, vol. 323, p. 127-143. https://doi.org/10.1144/SP323.6.

Gladkochub D., Pisarevsky S., Donskaya T., Natapov L., Mazukabzov A., Stanevich A., Sklyarov E., 2006. Siberian craton and its evolution in terms of Rodinia hypothesis. Episodes 29 (3), 169-174.

Ishihara S., 1977. The magnetite-series and ilmenite-series granitic rocks. Mining Geology 27 (145), 293-305. https://doi.org/10.11456/shigenchishitsu1951.27.293.

Johnson M.C., Rutherford M.J., 1989. Experimental calibration of the aluminium-in-hornblende geobarometer with application to Long Valley Caldera (California) volcanic rocks. Geology 17 (9), 837-841. https://doi.org/10.1130/00917613(1989)017<0837:ECOTAI >2.3.CO;2.

Kushch L.V., Makrygina V.A., 2014. Comparison of 2.1-1.6 Ga fault-line alkaline metasomatic rocks and granitoids from regional fault zones on the southern framing of the Siberian craton. Russian Geology and Geophysics 55 (3), $323-$ 334. https://doi.org/10.1016/j.rgg.2014.01.014.

Kuznetsov V.G., Khrenov P.M. (Eds.), 1989. Geological map of the Irkutsk region and adjacent territories. Scale 1:500000. VSEGEI, Leningrad (in Russian) [Геологическая карта Иркутской области и сопредельных территорий / Ред. В.Г. Кузнецов, П.М. Хренов. Масштаб 1:500000. Л.: ВСЕГЕИ, 1989].

Larin A.M., Kotov A.B., Sal'nikova E.B., Kovach V.P., Makar'ev L.B., Timashkov A.N., Berezhnaya N.G., Yakovleva S.Z., 2000. New data on the age of granites of the Kodar and Tukuringra complexes, Eastern Siberia: geodynamic constraints. Petrology 8 (3), 238-249.

Larin A.M., Sal'nikova E.B., Kotov A.B., Glebovitsky V.A., Yakovleva S.Z., Sryvtsev N.A., Anisimova I.V., Tolkachev M.D., 2009. Age and tectonic setting of charnokites of the Tatarnik complex (northwestern part of the Baikal region). Doklady Earth Sciences 429A (9), 1447-1450. https://doi.org/10.1134/S1028334X09090086.

Larin A.M., Sal'nikova E.B., Kotov A.B., Kovalenko V.I., Rytsk E.Yu., Yakovleva S.Z., Berezhnaya N.G., Kovach V.P., Buldygerov V.V., Sryvtsev N.A., 2003. The North Baikal volcanoplutonic belt: age, formation duration, and tectonic setting. Doklady Earth Sciences 392 (7), 963-967.

Larin A.M., Sal'nikova E.B., Kotov A.B., Makar'ev L.B., Yakovleva S.Z., Kovach V.P., 2006. Early Proterozoic syn- and postcollisional granites in the northern part of the Baikal fold area. Stratigraphy and Geological Correlation 14 (5), 463-474. https://doi.org/10.1134/S0869593806050017.

Leake B.E., Woolley A.R., Arps C.E.S., Birch W.D., Gilbert M.C., Grice J.D., Hawthorne F.C., Kato A., Kisch H.J., Krivovichev V.G., Linthout K., Laird J., Mandarino J., Maresch W.V., Nickel E.H., Rock N.M.S., Schumacher J.C., Smith D.C., Stephenson N.C.N., Ungaretti L., Whittaker E.J.W., Youzhi G., 1997. Nomenclature of amphiboles: report of the subcommittee on amphiboles of the international mineralogical association commission on new minerals and mineral names. Mineralogical Magazine 61 (2), 295-321. https://doi.org/10.1180/minmag.1997.061.405.13.

Levitskii V.I., Mel'nikov A.I., Reznitskii L.Z., Bibikova E.V., Kirnozova T.I., Kozakov I.K., Makarov V.A., Plotkina Yu.V., 2002. Early Proterozoic postcollisional granitoids in southwestern Siberian craton. Geologiya i Geofizika (Russian Geology and Geophysics) 43 (8), 679-692.

Loiselle M.C., Wones D.R., 1979. Characteristics and origin of anorogenic granites. In: Geological Society of America Abstracts with Programs 11, 468.

Morimoto N., 1988. Nomenclature of pyroxenes. Mineralogy and Petrology 39 (1), 55-76. https://doi.org/10.1007/ BF01226262.

Neymark L.A., Larin A.M., Yakovleva S.Z., Sryvtsev N.A., Buldygerov V.V., 1991. New data on age of the Akitkan group of Baikal-Patom fold area, from the results of U-Pb dating of zircons. Doklady AN SSSR 320 (1), 182-186 (in Russian) [Неймарк Л.А., Ларин А.М., Яковлева С.З., Срывцев Н.А., Булдыгеров В.В. Новые данные о возрасте пород акитканской серии Байкало-Патомской складчатой области по результатам U-Pb датирования цирконов // Доклады АН СССР. 1991. Т. 320. № 1. С. 182-186].

Neymark L.A., Larin A.M., Nemchin A.A., Ovchinnikova G.V., Rytsk E.Y., 1998. Anorogenic nature of magmatism in the Northern Baikal volcanic belt: Evidence from geochemical, geochronological (U-Pb), and isotopic $(\mathrm{Pb}, \mathrm{Nd}) \mathrm{data}$. Petrology 6 (2), 124-148.

Nozhkin A.D., Bibikova E.V., Turkina O.M., Ponomarchuk V.A., 2003. Study of porphyritic subalkalic granites of the Taraka pluton (Yenisei Range). Geologiya i Geofizika (Russian Geology and Geophysics) 44 (9), 879-889.

Panteeva S.V., Gladkochoub D.P., Donskaya T.V., Markova V.V., Sandimirova G.P., 2003. Determination of 24 trace elements in felsic rocks by inductively coupled plasma mass spectrometry after lithium metaborate fusion. Spectrochimica Acta Part B: Atomic Spectroscopy 58 (2), 341-350. https://doi.org/10.1016/S0584-8547(02)00151-9.

Pearce J.A., 1996. Sources and settings of granitic rocks. Episodes 19 (4), 120-125.

Petrova Z.I., Makrygina V.A., Antipin V.S., 1997. Petrological and geochemical correlations between rapakivi granites and acid volcanics in the southern fringing of the Siberian platform. Petrology 5 (3), 258-277.

Poller U., Gladkochub D., Donskaya T., Mazukabzov A., Sklyarov E., Todt W., 2005. Multistage magmatic and metamorphic evolution in the Southern Siberian craton: Archean and Paleoproterozoic zircon ages revealed by SHRIMP and TIMS. Precambrian Research 136 (3-4), 353-368. https://doi.org/10.1016/j.precamres.2004.12.003.

Rosen O.M., 2003. The Siberian craton: Tectonic zonation and stages of evolution. Geotectonics 37 (3), 175-192. 
Rosen O.M., Condie K.C., Natapov L.M., Nozhkin A.D., 1994. Archean and Early Proterozoic evolution of the Siberian craton: A preliminary assessment. In: K.C. Condie (Ed.), Archean crustal evolution. Elsevier, Amsterdam, p. 411-459.

Savel'eva V.B., Bazarova E.P., 2012. The Early Proterozoic Primorskii complex of rapakivi granites (western Cisbaikalia): geochemistry, crystallization conditions, and ore potential. Russian Geology and Geophysics 53 (2), 147-168. https://doi.org/10.1016/j.rgg.2011.12.012.

Scoates J.S., Frost C.D., Mitchell J.N., Lindsley D.H., Frost B.R., 1996. Residual-liquid origin for a monzonite intrusion in a mid-Proterozoic anorthosite complex: the Sybille intrusion, Laramie anorthosite complex, Wyoming. Geological Society of America Bulletin 108 (11), 1357-1371. https://doi.org/10.1130/0016-7606(1996)108<1357:RLOFAM> 2.3.CO;2.

Sharpenok L.N., Kostin A.E., Kukharenko E.A., 2013. Total-alkali-silica TAS diagram for chemical classification and identification of plutonic rocks. Regional'naya Geologiya i Metallogeniya (56), 40-50 (in Russian) [Шарпенок Л.Н., Костин A.E., Кухаренко E.A. TAS-диаграмма сумма щелочей - кремнезем для химической классификации и диагностики плутонических пород // Региональная геология и металлогения. 2013. № 56. С. 40-50]

Shokhonova M.N., Donskaya T.V., Gladkochub D.P., Mazukabzov A.M., Paderin I.P., 2010. Paleoproterozoic basaltoids in the North Baikal volcanoplutonic belt of the Siberian craton: age and petrogenesis. Russian Geology and Geophysics 51 (8), 815-832. https://doi.org/10.1016/j.rgg.2010.07.001.

Skjerlie K.P., Johnston A.D., 1993. Fluid-absent melting behavior of an F-rich tonalitic gneiss at mid-crustal pressures: implications for the generation of anorogenic granites. Journal of Petrology 34 (4), 785-815. https://doi.org/ 10.1093/petrology/34.4.785.

Sryvtsev N.A., Sandimirova G.P., Kutyavin E.P., Koltsova T.V., Manuylova M.M., Plusnin G.S., 1980. About age the twopyroxene granitoids of Tatarnik complex of Northwest Baikal region. In: L.N. Ovchinnikov (Ed.), Geochronology of Eastern Siberia and the Russian Far East. Nauka, Moscow, p. 101-110 (in Russian) [Срывцев Н.А., Сандимирова Г.П., Кутявин Э.П., Кольцова Т.В., Мануйлова М.М., Плюснин Г.С. О возрасте двупироксеновых гранитоидов татарниковского комплекса Северо-Западного Прибайкалья // Геохронология Восточной Сибири и Дальнего Востока / Ред. Л.Н. Овчинников. М.: Наука, 1980. С. 101-110].

Sun S., McDonough W.F., 1989. Chemical and isotopic systematics of oceanic basalts: implications for mantle composition and processes. In: Saunders A.D., Norry M.J. (Eds.), Magmatism in the oceanic basins. Geological Society, London, Special Publications, vol. 42, p. 313-345. https://doi.org/10.1144/GSL.SP.1989.042.01.19.

Turkina O.M., 2005. Proterozoic tonalites and trondhjemites of the southwestern margin of the Siberian craton: isotope geochemical evidence for the lower crustal sources and conditions of melt formation in collisional settings. Petrology 13 (1), 35-48.

Turkina O.M., Bibikova E.V., Nozhkin A.D., 2003. Stages and geodynamic settings of Early Proterozoic granite formation on the southwestern margin of the Siberian craton. Doklady Earth Sciences 389 (2), 159-163.

Turkina O.M., Kapitonov I.N., 2017. Lu-Hf isotope composition of zircon as an indicator of the sources for Paleoproterozoic collisional granites (Sharyzhalgai uplift, Siberian craton). Russian Geology and Geophysics 58 (2), 149-164. https://doi.org/10.1016/j.rgg.2017.01.001.

Turkina O.M., Nozhkin A.D., Bayanova T.B., 2006. Sources and formation conditions of Early Proterozoic granitoids from the southwestern margin of the Siberian craton. Petrology 14 (3), 262-283. https://doi.org/10.1134/ S0869591106030040.

Wakita H., Schmitt R.A., Rey P., 1970. Elemental abundances of major, minor, and trace elements in Apollo 11 lunar rocks, soil and core samples. In: Proceedings of the Apollo 11 Lunar Science Conference, p. 1685-1717.

Watson E.B., Harrison T.M., 1983. Zircon saturation revisited: temperature and composition effects in a variety of crustal magma types. Earth and Planetary Science Letters 64 (2), 295-304. https://doi.org/10.1016/0012-821X(83) 90211-X.

Whalen J.B., Currie K.L., Chappel B.W., 1987. A-type granites: geochemical characteristics and petrogenesis. Contributions to Mineralogy and Petrology 95 (4), 407-419. https://doi.org/10.1007/BF00402202.

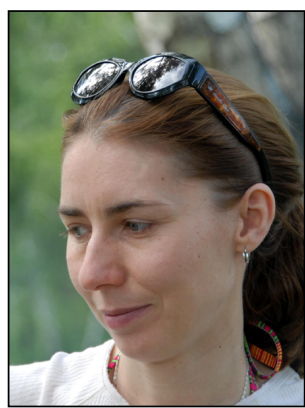

Татьяна Владимировна Донская, канд. геол.-мин. наук, в.н.с.

Институт земной коры СО РАН

664033, Иркутск, ул. Лермонтова, 128, Россия

e-mail: tanlen@crust.irk.ru

Tatiana V. Donskaya, Candidate of Geology and Mineralogy, Lead Researcher

Institute of the Earth's Crust, Siberian Branch of RAS

128 Lermontov street, Irkutsk 664033, Russia

e-mail: tanlen@crust.irk.ru 


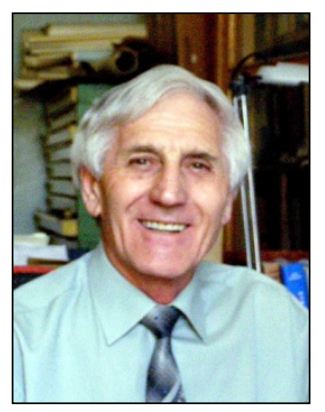

Анатолий Муталибович Мазукабзов, докт. геол.-мин. наук, в.н.с.

Институт земной коры СО РАН

664033, Иркутск, ул. Лермонтова, 128, Россия

e-mail: mazuk@crust.irk.ru

Anatoly M. Mazukabzov, Doctor of Geology and Mineralogy, Lead Researcher Institute of the Earth's Crust, Siberian Branch of RAS

128 Lermontov street, Irkutsk 664033, Russia

e-mail: mazuk@crust.irk.ru

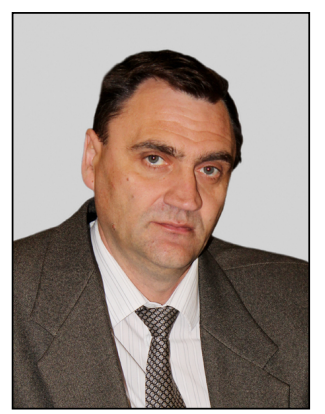

Дмитрий Петрович Гладкочуб, докт. геол.-мин. наук, член-корреспондент РАН, директор института Институт земной коры СО РАН

664033, Иркутск, ул. Лермонтова, 128, Россия

e-mail:dima@crust.irk.ru

Dmitry P. Gladkochub, Doctor of Geology and Mineralogy, Corresponding Member of RAS,

Director of the Institute

Institute of the Earth's Crust, Siberian Branch of RAS

128 Lermontov street, Irkutsk 664033, Russia

e-mail: dima@crust.irk.ru 